\title{
Historical Volcanism and the State of Stress in the East African Rift System
}

\author{
G. Wadge ${ }^{1 *}$, J. Biggs ${ }^{2}$, R. Lloyd ${ }^{2}$ and J.-M. Kendall ${ }^{2}$ \\ ${ }^{1}$ Centre for Observation and Modelling of Earthquakes, Volcanoes and Tectonics (COMET), Department of Meteorology, \\ University of Reading, Reading, UK, ${ }^{2}$ Centre for Observation and Modelling of Earthquakes, Volcanoes and Tectonics \\ (COMET), School of Earth Sciences, University of Bristol, Bristol, UK
}

\section{OPEN ACCESS}

Edited by:

Agust Gudmundsson,

University of London, UK

Reviewed by:

Roberto Sulpizio,

University of Bari, Italy

Alessandro Tibaldi

University of Milano-Bicocca, Italy

*Correspondence:

G. Wadge

g.wadge@reading.ac.uk

Specialty section: This article was submitted to Volcanology,

a section of the journa

Frontiers in Earth Science

Received: 25 May 2016 Accepted: 02 September 2016

Published: 30 September 2016

Citation:

Wadge G, Biggs J, Lloyd R and Kendall J-M (2016) Historical Volcanism and the State of Stress in the East African Rift System.

Front. Earth Sci. 4:86 doi: 10.3389/feart.2016.00086
Crustal extension at the East African Rift System (EARS) should, as a tectonic ideal, involve a stress field in which the direction of minimum horizontal stress is perpendicular to the rift. A volcano in such a setting should produce dykes and fissures parallel to the rift. How closely do the volcanoes of the EARS follow this? We answer this question by studying the 21 volcanoes that have erupted historically (since about 1800) and find that 7 match the (approximate) geometrical ideal. At the other 14 volcanoes the orientation of the eruptive fissures/dykes and/or the axes of the host rift segments are oblique to the ideal values. To explain the eruptions at these volcanoes we invoke local (non-plate tectonic) variations of the stress field caused by: crustal heterogeneities and anisotropies (dominated by NW structures in the Protoerozoic basement), transfer zone tectonics at the ends of offset rift segments, gravitational loading by the volcanic edifice (typically those with 1-2 km relief) and magmatic pressure in central reservoirs. We find that the more oblique volcanoes tend to have large edifices, large eruptive volumes, and evolved and mixed magmas capable of explosive behavior. Nine of the volcanoes have calderas of varying ellipticity, 6 of which are large, reservoir-collapse types mainly elongated across rift (e.g., Kone) and 3 are smaller, elongated parallel to the rift and contain active lava lakes (e.g., Erta Ale), suggesting different mechanisms of formation and stress fields. Nyamuragira is the only EARS volcano with enough sufficiently well-documented eruptions to infer its long-term dynamic behavior. Eruptions within $7 \mathrm{~km}$ of the volcano are of relatively short duration ( $<100$ days), but eruptions with more distal fissures tend to have lesser obliquity and longer durations, indicating a changing stress field away from the volcano. There were major changes in long-term magma extrusion rates in 1977 (and perhaps in 2002) due to major along-rift dyking events that effectively changed the Nyamuragira stress field and the intrusion/extrusion ratios of eruptions.

\section{Keywords: crustal stress, historical eruptions, East African Rift, oblique motion, eruption dynamics}

\section{INTRODUCTION}

The East African Rift System (EARS) is a natural laboratory for studies of active continental extension (Ebinger, 2005, 2012). On a continental scale, the stress field of the EARS is governed by mantle buoyancy forces, which drive plate motions and generate dynamic topography; viscous resisting tractions in the plate and mantle; and the gravitational potential energy due to the structure of the crust and lithosphere (e.g., Stamps et al., 2010; Kendall and Lithgow-Bertelloni, 2016). The stresses generated are on the order of $100 \mathrm{MPa}$, and are not sufficient to break old, 
cold lithosphere, and continental break-up results from a combination of mechanical stretching, pre-existing weaknesses and thermal weakening by intrusions (Gudmundsson, 2000; Buck, 2004, 2006; Buck et al., 2006; Bialas et al., 2010; Corti, 2012; Kendall and Lithgow-Bertelloni, 2016).

On a local scale, the stress field plays a major role in determining the orientation of magmatic intrusions, particularly dyke formation along extensional fractures and consequently the alignment of fissures and vents at the surface. Work at another divergent plate boundary setting, in Iceland (Gudmundsson, 2000), and elsewhere has produced many insights relevant to our study such as: the different behaviors produced by point and cavity models of magmatic pressure (Gudmundsson, 2006), the mechanical anisotropy of host rocks and the effect this can have on dykes reaching the surface (Gudmundsson, 2003; Gudmundsson and Philipp, 2006), the significance of sill formation on the creation of shallow magma reservoirs beneath central volcanoes (Gudmundsson, 2006) and topographycontrolled stress fields guiding the propagation paths of dykes (Acocella and Tibaldi, 2005). Recent examples in the EARS include the 100-km long Dabbahu dyke intrusion in Afar (Wright et al., 2006) and the 2007 Lake Natron dyke intrusion in Tanzania (Calais et al., 2008; Biggs et al., 2009), which were both aligned perpendicular to the plate motion. However, superimposed upon the large-scale stress regime are local stresses related to topography, seismic and magmatic processes (e.g., Biggs et al., 2013b; Maccaferri et al., 2014; Pagli et al., 2014) and which are also seen to control the orientation of magmatic features, such as the Jebel al Tair eruption in the Red Sea (Xu and Jonsson, 2014) and the orientation of fissures around Oldoinyo Lengai in Tanzania (Muirhead et al., 2015).

While GPS measurements can be used to map plate velocities (e.g., Saria et al., 2014), the density of stations is not sufficient to map the short-wavelength spatial and temporal variability of the strain field. Satellite-based InSAR measurements provide highresolution maps of displacement and have been used to measure regional velocity fields (e.g., Pagli et al., 2014), and once sufficient data is archived Sentinel-1 satellites should routinely provide high resolution and precision measurements on a continental scale.

The purpose of this study is to improve understanding of the roles that crustal stresses have on volcanism in the EARS. In particular, we focus on how the stress field may have played a role in eruptions since 1800, the first such general review. Written records of volcanic eruptions in the EARS extend as far back as the 1840 s to 1880 s, and oral recollections by inhabitants take the record back to about 1800 in places. In many cases, these records can be used to link lava flows, vents and fissures seen in satellite imagery to specific events, and thus estimate the geometry of the feeding system and volume erupted. More recently (20022015), geophysical techniques have been used to observe several rifting episodes in the EARS, including the eruptions from the Western Branch (Nyamuragira, Nyiragongo), Eastern Branch (Oldoinyo Lengai) and Afar (Dabbahu-Manda Harraro, Erte Ale, Alu-Dalafilla, Nabro). In these cases, geodetic and seismic data provide a detailed view of the magmatic plumbing system, which can be combined with studies of erupted products.
In Section Factors that Could Affect Stress and Strain in the EARS, we briefly review the sources and measurements of crustal stress in the EARS and in Section Historical Record summarize the observations of the 21 historical eruptions, and in particular, the orientation of feeding dykes and local structure. In Section Discussion, we synthesize these observations in terms of the magmatic and eruption processes, and the orientation and morphology of crustal and volcanic structures. We conclude that local variations in the stress field, including edifice loading, magma pressure, and transfer zone tectonics as well as crustal heterogeneities and anisotropies play a significant role in the 14 of the 21 historical eruptions, and find evidence that temporal variations in the stress field control eruption dynamics.

\section{FACTORS THAT COULD AFFECT STRESS AND STRAIN IN THE EARS}

The first-order plate tectonic model motion for the EARS, supported by GPS measurements (e.g., Saria et al., 2014), shows motion to the ENE in the north, and motion to the ESE in the south of the Arabian and Somalian plates respectively relative to the Nubian plate (Figure 1). The boundary forces at the plates' sides and bases and the buoyancy forces from lateral variations in gravitational potential energy are responsible for this motion and the resultant horizontal stress field (Craig et al., 2011; Stamps et al., 2014; Figure 2A). A normal faulting regime (vertical stress component $\left(\sigma_{\mathrm{V}}\right)$ greater than the two horizontal stress components: $\sigma_{\mathrm{v}}=\sigma_{1}>\sigma_{2}>\sigma_{3}$ ) dominates in the EARS, with a strike slip regime (vertical stress component is intermediate relative to the horizontal stress components: $\sigma_{1}>\sigma_{\mathrm{v}}>\sigma_{3}$ ) more evident in some places (e.g., Asal-Ghoubbet Rift, Delvaux and Barth, 2009). For the normal extensional regime, the direction of the maximum horizontal stress $S_{\mathrm{HMAX}}=\sigma_{2}$, should correspond to the direction of dyke propagation, orthogonal to the opening direction or the minimum horizontal stress $\left(S_{\mathrm{HMIN}}=\sigma_{3}\right)$.

The vertical and horizontal stresses in the Earth's crust generally correspond to the principal stresses (Amadei and Stephansson, 1997). In rift zones the vertical stress is usually the greatest and one of the horizontal stresses the least. The vertical stress in the Earth's crust increases linearly at a rate of about $26 \mathrm{MPa} / \mathrm{km}$ (McGarr and Gay, 1978) and is often of near constant orientation, for example throughout the $9 \mathrm{~km}$-deep KTB borehole (Brudy et al., 1997). The horizontal stress is much more variable and the differential value $\left(\mathrm{S}_{\mathrm{HMAX}^{-}}\right.$ $\mathrm{S}_{\text {HMIN }}$ ) may be several tens of MPas. This is usually because of abrupt changes in the material properties (e.g., Young's modulus) of different lithologies (Gudmundsson, 2006, 2011a). Also the orientation of the stress field is much more consistent over extended regions than the magnitudes of the stress components.

The principles of the analysis of the stress field in volcanic systems began with Anderson (1936). Nakamura (1977) first showed how volcano stress fields interacted with (plate) tectonic stress fields, such that dyke fissures and surface vents tend to align with the local direction of $\sigma_{1}$. The curvilinear nature of dyke swarms in composite stress fields was demonstrated at the 


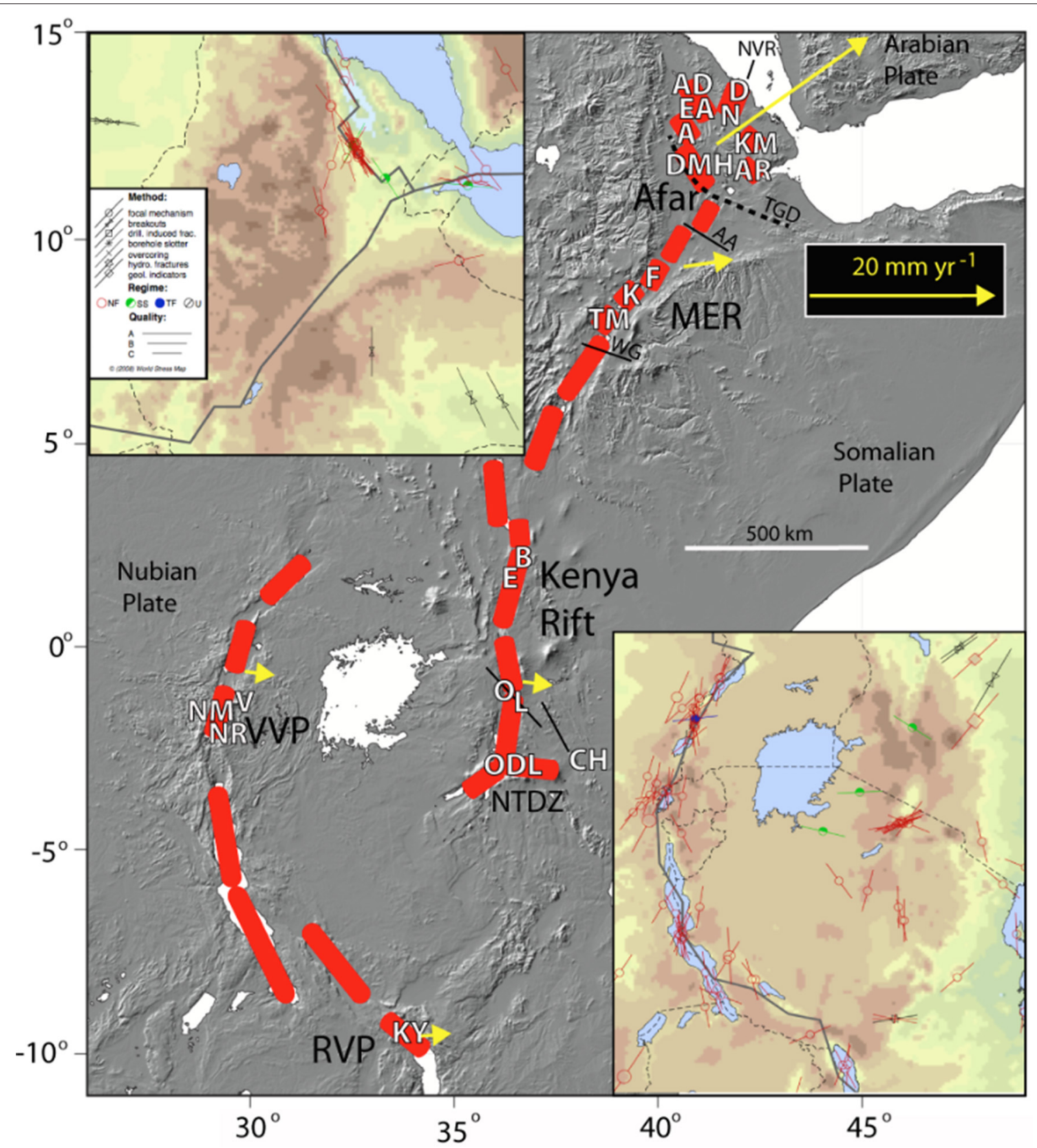

FIGURE 1 | Sketch map of the EARS showing the main rift segments in red. The historically active volcanoes are labeled in white according to their abbreviation in Table 1. MER, Main Ethiopian Rift; WP, Virunga Volcanic Province; NTDZ, North Tanzanian Divergence Zone; and RVP, Rungwe Volcanic Province. The dashed black line in Afar is the Tendahu-Goba'ad Discontinuity. The continuous black lines are inherited discontinuities (AA, Ayelu-Amoissa; WG, Wendo-Genet) discussed in the text. Yellow arrows are vectors of Somalian and Arabian plate motion relative to the Nubian plate. The two colored topographic maps inset in the upper left and lower right corners are from the 2008 version of the World Stress Map (Heidbach et al., 2010) showing locations of the primary crustal stress measurements. Each line symbol is oriented along the maximum horizontal principal stress direction, modulated by method (symbol), inferred tectonic setting (color) and quality (length of line). The thick lines are the plate boundaries, the dashed lines are national boundaries.

Spanish Peaks center (Muller and Pollard, 1977). Multiple factors combining to generate such composite fields have been advocated and analyzed: loading due to the edifice (e.g., Dahm, 2000; Pinel and Jaupart, 2000; Maccaferri et al., 2011) and unloading (e.g., Maccaferri et al., 2014), the effects of volcano morphology (e.g., Tibaldi et al., 2014; Corbi et al., 2015), the generation of magma reservoirs and calderas (e.g., Tibaldi, 2015) and the anisotropy of host rocks (Gudmundsson, 2011a). Many dykes do not propagate all the way to the surface, but may be arrested by layers with variable associated stress (Gudmundsson and Philipp, 2006). Indeed, as we shall see, several EARS volcanoes have demonstrable intrusive to extrusive magma volumetric ratios $>1$. 


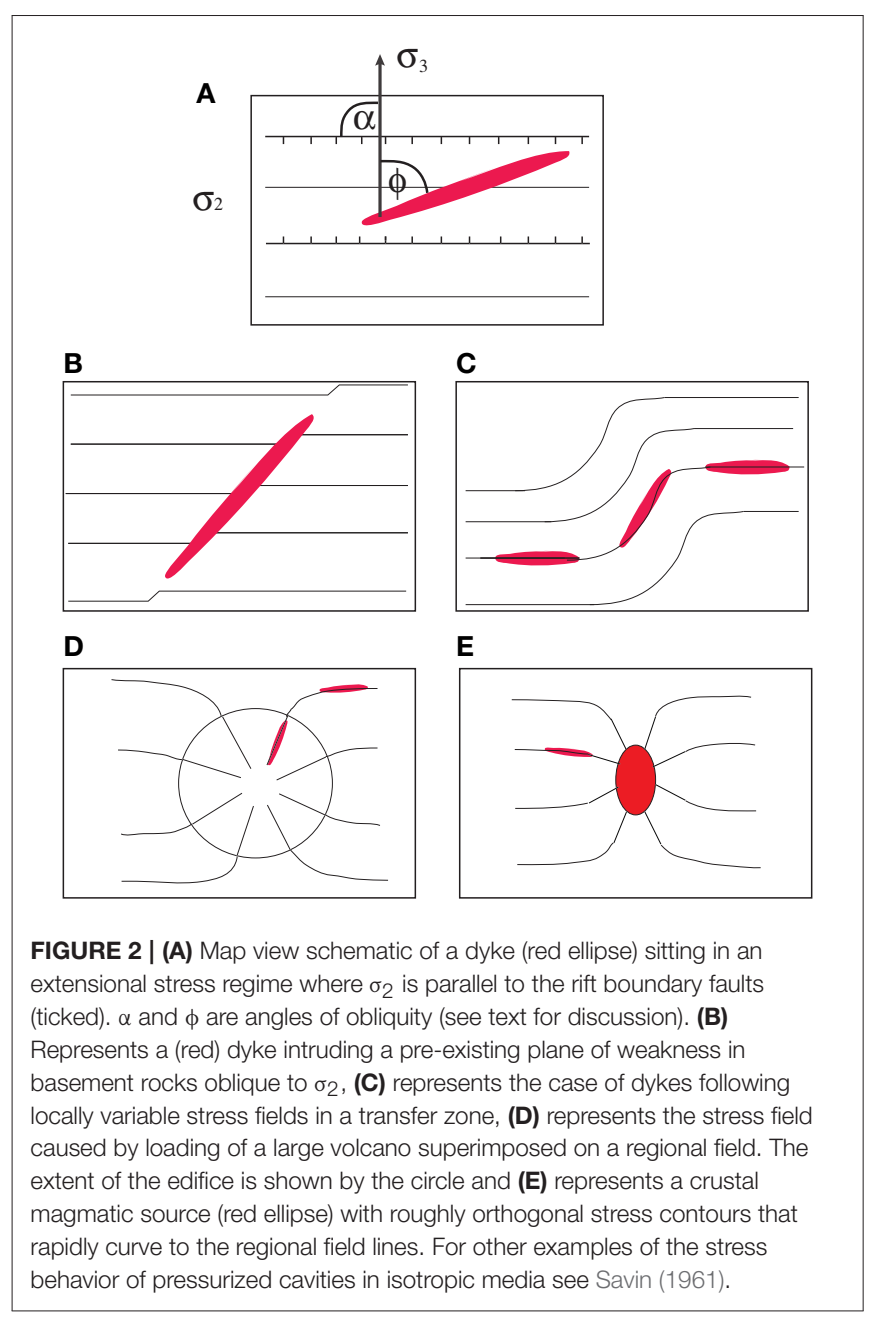

Rivalta et al. (2015) provide an overview from the perspective of dyke propagation.

The geometric relationship between plate motion, plate boundary orientation and the resulting structures can be defined according to the model of Tuckwell et al. (1996), who classified geometrical models of mid-ocean ridge spreading, three of which (orthogonal, oblique, transtension) are observed in nature. Robertson et al. (2015) used a similar system to describe the geometry of rift extension, using the Kenyan Rift as an example. The three models can be described using two angles: $\alpha$ is the angle between the rift azimuth and the plate motion direction $\left(\mathrm{S}_{\mathrm{HMIN}}\right)$ and $\phi$ is the angle between the fault or dyke azimuth and the plate motion direction. Figure 2A illustrates the relationship of the two angles. If $\alpha=\phi=90^{\circ}$, there is zero obliquity and the rift is considered to be orthogonal, causing normal faulting along the rift margins and rift-parallel dykes to occur in the rift valley. If $\alpha=\phi$ and the dyke is parallel to the rift and both are oblique to the spreading direction then the rift is described as oblique. If $\phi=\alpha / 2+45^{\circ}$, the dyke and plate motion are oblique to the rift and the rift is said to be in transtension.

It is commonly observed in the EARS that the direction of dyke propagation is not orthogonal to the first order plate motion, indicating that $S_{\text {HMIN }}$ is both regionally and locally variable and that continental rifting is rarely purely orthogonal (Figure 2A; e.g., Gudmundsson, 2006).

The stress field can be measured locally, but very sparsely, by several methods operating at different length scales (Amadei and Stephansson, 1997) from earthquake focal mechanisms (Delvaux and Barth, 2009), and seismic anisotropy (Kendall et al., 2005) over tens of kilometers, borehole breakouts at a meter scale and hydro-fracturing over tens to hundreds of meters (Heidbach et al., 2010). In the EARS these local measurements suggest a regional stress field associated with $\sim 100 \mathrm{~km}$-long rift segments. For example focal mechanisms suggest $\mathrm{S}_{\mathrm{HMIN}}=\mathrm{WNW}$-ESE in the Main Ethiopian Rift (MER) and the Virunga Volcanic Province (VVP); N-S in Natron and ENE-WSW in northern Afar (Delvaux and Barth, 2009; Figure 1). On even smaller scales, particularly around large volcanic edifices, the stress field may be even more complex.

We now review the main ways in which the stress and corresponding strain field can be modified locally in the EARS. Regional and local variations in the stress field are associated with (1) regions of complex rift geometry where heterogeneities favor reactivation of non-optimally oriented structures or in transfer zones linked to offsets between rift segments, or (2) magmatic processes including subsurface magma pressure or loading by volcanic edifices (e.g., Keir et al., 2015).

\section{Complexities in Rift Geometry}

Variations in density, stiffness (Young's modulus), composition and fracturing of the crust or upper mantle can potentially impact the stress gradients and elastic behavior of the rocks hosting dykes. This applies both to the pre-rifting basement rocks, mainly Proterozoic in age, whose inherited properties, for example crustal fault systems, may have become re-activated during rifting (Coblentz and Sandiford, 1994; Corti, 2009; Figure 2B) and to recent structures, including active rift faults and caldera ring faults, which have been shown to act as pathways for both magmatic and hydrothermal fluids (Hutchison et al., 2015). The most obvious heterogeneity is the presence of the Tanzanian Craton (Koptev et al., 2015) which effectively guides the rift as it splits into two arms around a deep keel of Proterozoic rocks.

Pre-existing structures and fabrics that extend to the surface are usually well-mapped using traditional geological techniques or geomagnetic survey, but deeper heterogeneities cannot be observed directly and we rely on the variability of velocity and polarization in seismic records to map anisotropy of the crust and upper mantle. Shear wave splitting techniques using body phases such as SKS are best for exploring mineral (olivine) orientation due to flow in the mantle (Hammond et al., 2014), while teleseismic receiver functions have been used to infer multiparameter anisotropy of upper mantle and lower crust melt geometry (Hammond, 2014). Shear wave splitting using local earthquakes provides the best resolution in the upper crust and is the most relevant to studies of the stress field beneath local volcanic centers (Keir et al., 2011a).

Offsets in the rift occur because rift segments form in isolation, but eventually grow and interact, causing complexities in the field geometry and local stress field. These include normal fault initiation from tension fractures and en echelon linking of faults 
(Gudmundsson et al., 2010; Gudmundsson, 2011b, chapter 14). At mid-ocean ridges, the motion between segments is taken up on transform faults, but during rift development, there may be complex zones of mixed normal, strike-slip (e.g., Spacapan et al., 2016) and even compressional tectonics (e.g., Sachau et al., 2015). These can be several tens of kilometers in extent (Ebinger, 1989; Morley et al., 1990; Figure 2C) and are referred to as transfer or accommodation zones.

\section{Magmatic and Volcanic Processes}

Volcanic edifices load the crust locally, modifying the stress field. In the vertical plane, differential stress decays in proportion to the edifice radius (Dahm, 2000) and has a negligible effect below the upper crust. The principal stresses also have curving trajectories focused at the point of greatest load beneath the highest part of the edifice (Dahm, 2000). In combination with an extensional tectonic stress field, the effect in the horizontal plane is a radial pattern of maximum compressive stress trajectories within a distance equivalent to the edifice radius, outside of which they bend to become parallel with the tectonic maximum stress trajectory (Figure 2D). Volcanoes with a non-circular footprint could produce an asymmetrical stress field (Acocella and Neri, 2009). Roman and Jaupart (2014) argued that this focusing effect tends to lead to the creation of a magma reservoir, which in turn leads to more evolved (buoyant) magmas, effectively preventing the rise of basaltic magma centrally. Gudmundsson (2011a) also showed that horizontal discontinuities can deflect magma from dykes into sills and can enhance the tendency to build a magma reservoir. To reach the surface the stress field along the propagation path of the dyke must be close to homogeneous (Gudmundsson and Philipp, 2006). To achieve this some dykes will tend to follow lateral paths, often breaking the surface at the edges of the edifice (Kervyn et al., 2009).

Ignoring stress concentrations around the reservoir itself, edifice loading may therefore have three first-order effects on volcanic behavior:

- Radial dykes, which beyond the edifice curve into the regional direction of maximum horizontal stress,

- A central, shallow magma reservoir,

- Silicic magmas developing in the reservoir, enabling major explosive eruptions and the mingling of contrasting magmas.

The creation of a rift valley itself produces a linear gravity low that can have the opposite effect to loading, in which magma follows an upward curving stress trajectory and away from a central magma source beneath the valley center (Maccaferri et al., 2014). This may explain the occurrence of some pre-historic volcanic eruptions outside of the rift. Individual fault scarps with relief less than $100 \mathrm{~m}$ can influence the trajectory of dyke propagation and focus magmatic pathways into the footwall (Maccaferri et al., 2015).

A large volume of magma may accumulate in the crust because of an inability to rise further. If the magma pressure rises above lithostatic it will exert a positive normal stress on the reservoir walls, eventually leading to one of many fracture initiations and dyke propagations. Gudmundsson (2012) suggests that over the long-term reservoirs with irregular boundaries are thermally and mechanically unstable and will tend to evolve to smoother equilibrium geometries. Most InSAR images of deforming volcanoes, particularly in East Africa show a simple bulls-eye pattern of motion (e.g., Biggs et al., 2009, 2011), equivalent to the deformation produced by a point- or a spherical/ellipsoidalpressure source, in an isotropic half space, typically attributed to varying pressure within a magma reservoir (Figure 2E) and originally analyzed as a either a pressurized point (Anderson, 1936; Mogi, 1958) or pressurized cavity (Savin, 1961). While deformation is an indicator of an active magmatic system and can be shown to have a statistical link to the likelihood of eruption (Biggs et al., 2014), the mechanisms that produce deformation are varied, and implications for the stress field are poorly understood. Caldera systems, in particular, often experience surface deformation without leading to eruption, and this is often linked to changes in the hydrothermal system (e.g., Chiodini et al., 2012; Biggs et al., 2014). If the deformation is linked temporally to an eruption then the stress from a magmatic source can be distinguished from edifice loading (which may have a similar pattern but is static in time), or if the pressure source is wide enough to indicate mid- to deep-crustal levels, and from a geothermal reservoir whose internal pressure is variable. Shallow level dykes and sills with non-recoverable strain are relatively easy to identify from InSAR data (e.g., Bagnardi et al., 2013).

Our understanding of the spatial and temporal variability of stress fields in the EARS is hampered by a lack of measurements of the local stress tensors associated with volcanic events. The new generation of InSAR deformation data may provide improved temporal resolution of source mechanisms. These data need to be better linked to stress field modeling based on solid mechanics and fracture mechanics principles.

\section{HISTORICAL RECORD}

The evidence of volcanism associated with rifting in the EARS indicates a long and complex history (Baker et al., 1972). Holocene volcanism is scattered along much of the length of the EARS, but is sparse in places, such as the southwestern part of the Western Rift between the Virunga and Rungwe Volcanic Provinces (VVP, RVP, Figure 1). In north Afar, volcanic edifices are elongate shields with axial fissures (e.g., Alu-Dalafilla, Erta Ale, Alayta). Further south, central grabens within a faulted and fissured terrain and a central vent area with a subsided edifice are typical (e.g., Dubbahu-Manda Hararo, Ardoukoba, Kammourta) (Barnie et al., 2015). The Tendao-Goba'ad Discontinuity (TGD) marks the triple junction between the Nubian, Somalian and Arabian plates (Acton et al., 1991). South of this, in the MER, there is an increasingly well-developed rift valley morphology, large normal fault boundaries and central fissure swarms and cones (e.g., Fantale, Kone, Tullu Moje) and large central volcanoes, including calderas (e.g., Corbetti, O’a). Further south, the rift branches around the Tanzanian Craton, with greater seismicity in the western branch than the eastern branch. The southernmost volcanoes of the EARS are located in the Rungwe Province in northern Malawi (Fontijn et al., 2012), south of 
which, the rifting appears to be amagmatic (e.g., Biggs et al., 2010).

Written records of volcanic eruptions in the EARS extend as far back as the 1840 s to 1880 s, and oral recollections by inhabitants take the record back to about 1800 in places. This is reflected in the records of the Smithsonian Institution Global Volcanism Program (GVP), which are our starting point. We restrict ourselves to post-1800 data (sensu lato), and the record is almost certainly incomplete. Figure 3 shows a timeline of the eruptions divided into those in the Afar and those from with the rest of the EARS. Two features are notable, the concentration of eruptions during the 2002-2011 period and the lack of eruptions in Afar for most of the nineteenth century. The latter is likely due to under-reporting small lava flows from axial fissure segments.

We find 21 volcanoes with historically-recorded eruptions (Figure 1, Table 1), and these are representative of the types of volcanic activity recognized in the EARS over longer periods, with the exception of caldera collapse. The erupted volumes are estimates of widely varying uncertainty and we use them with caution. Most of the lava flows are of distinct outline and we have measured their areas from satellite imagery (GoogleEarth) at uncertainties of a few tens of percent. Mean thicknesses are estimated with uncertainties of 50-100\%. Our volume estimates in Table $\mathbf{1}$ have an indicative uncertainty of about $\pm 150 \%$. There is a range of four orders of magnitude in these eruption volumes and we think these data generally support the interpretations we later make (Figures 4, 7). The volume uncertainties for Nyamuragira, used in creating Figures 4, 5 are, relatively, less than this. Apart from Oldoinyo Lengai and Nyamuragira, no estimates of ash/tephra deposits are represented. Some GVP eruptions are so poorly reported or lacking in useful detail that they have been omitted (Meru, South Island/L. Turkana).

Whilst basalt/basanite/nephelinite lava is the sole product at 14 volcanoes, trachyte and comendite/rhyolite lava flows are well represented at 5 volcanoes and carbonatite lava at Oldoinyo Lengai. Major explosive eruptions occurred at 3 volcanoes: Dubbi, Nabro, and Oldoinyo Lengai, each with two distinctly different magmas involved. Out of an estimated $\sim 5.2 \mathrm{~km}^{3}$ of historically erupted lava only $6 \%$ is of silicic composition. However, this does not include estimates of the silicic tephra components of the Dubbi and Nabro eruptions, so the actual total and proportion of silicic magma is higher.
Most of the volcanoes have erupted just once in the past 200 years. Erta Ale and Nyiragongo have summit lava lakes, with semi-continuous overturning of magma, but the details of occasional overflows we ignore. Two volcanoes have had multiple significant eruptions: Oldoinyo Lengai and Nyamuragira. The latter has such a rich and complex record that we restrict ourselves to the most recent, 2011-2012 eruption in Tables 1-3, but also discuss the earlier record later.

On seven occasions since 2002 detailed geophysical observations from InSAR, GPS and seismicity have been made of eruptions and interpreted in terms of the transport of magma through crustal reservoirs, dykes and onto the surface. We describe these events in Section Geophysically-Observed Eruptions (2002-2015) and in Section Historically-Recorded Eruptions (1800-2002) describe eruptions prior to this time, when observations were mainly based on historical accounts and subsequent mapping.

\section{Geophysically-Observed Eruptions (2002-2015) \\ Nabro (2011)}

This 40-day long eruption (Sealing, 2013) had bimodal products with an initial trachyte ash plume that reached the stratosphere and released a huge amount of sulfur dioxide: $1.6 \pm 0.3 \mathrm{Tg} \mathrm{SO}_{2}$ (Carboni et al., 2015), the largest single global emission in the 4 years from 2008 to 2012. The plume was continuous for the first 5 days, after which a trachybasaltic lava flow with a volume of $0.2-0.3 \mathrm{~km}^{3}$ developed from a $2 \mathrm{~km}$-long $\mathrm{NW}$-trending fissure originating at the pit crater which was then infilled with lava. Goitom et al. (2015) modeled a dyke beneath this fissure. On the basis of post-eruption deformation and seismicity, Hamlyn et al. (2014) argued for a $7 \mathrm{~km}$-deep reservoir with a thrust fault above.

\section{Alu-Dalafilla (2008)}

A brief (4 days), high extrusion rate eruption from an en echelon fissure ( $3.5 \mathrm{~km}$ long) on the rift axis between two central volcanoes of the Erta Ale segment, produced a $16 \mathrm{~km}^{2}$ basalt lava flow field. InSAR modeling required a dyke extending down from the fissure to a $\sim 1 \mathrm{~km}$ deep, $10 \mathrm{~km}$-long, sill and below the center of that, a Mogi (spherical) source at about $4 \mathrm{~km}$ depth (Pagli et al., 2012). During the eruption, the dyke inflated by about $5 \times 10^{6} \mathrm{~m}^{3}$ whilst the sill and Mogi source contracted by $23 \times 10^{6} \mathrm{~m}^{3}$ and

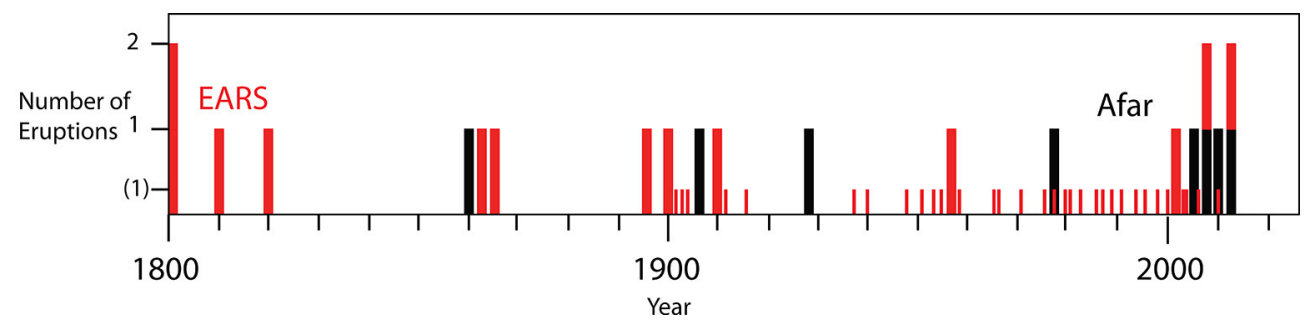

FIGURE 3 | Timeline (1800-2025) of the historical eruptions; one bar of height $\mathbf{1}$ (y-axis) represents one eruption for that year, 2 represents 2 eruptions. Afar eruptions are shown in black, those in the rest of the EARS in red. The small [height (1)] red bars are the twentieth and twenty first century eruptions of Nyamuragira before 2012 and the eruptions of Oldoinyo Lengai in 1916, 1940, and 1966. Note the preponderance of EARS eruptions between 1800 and 1900. 


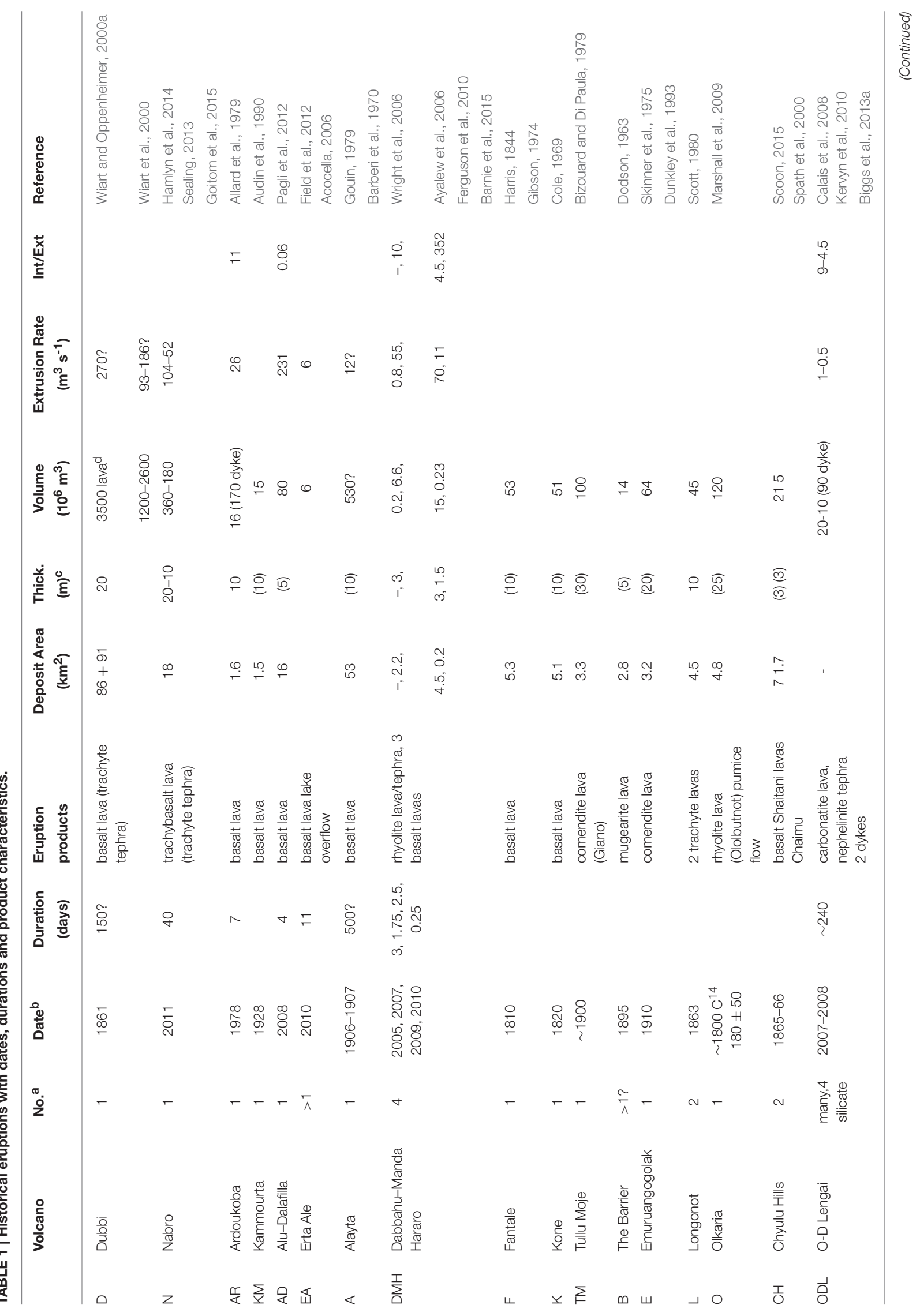




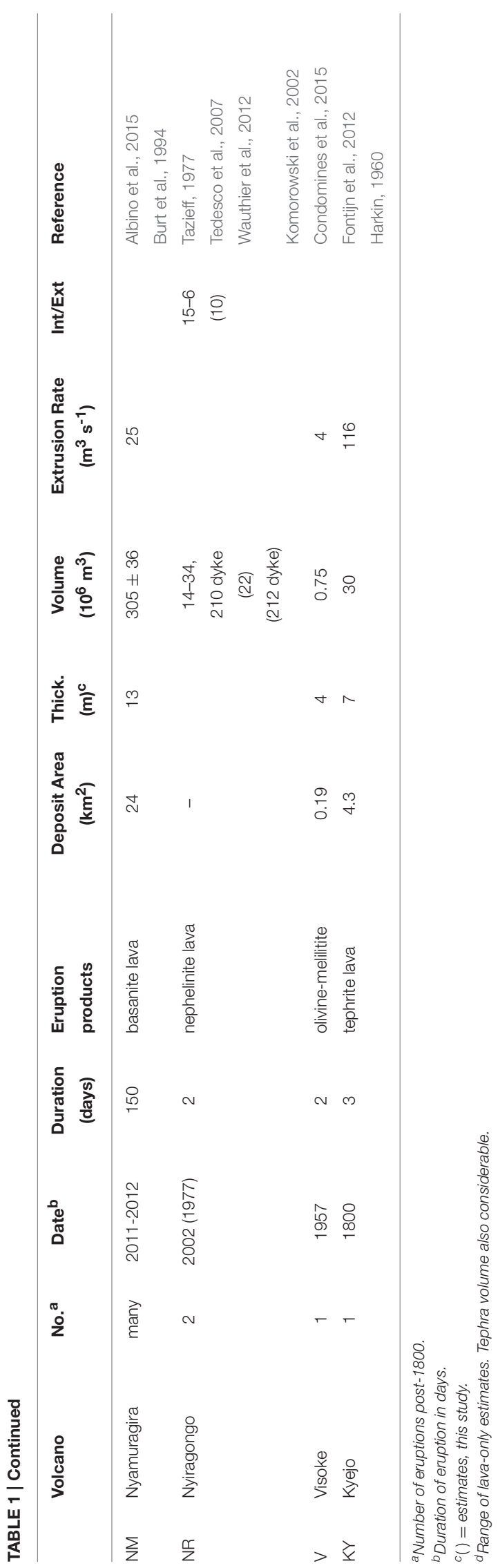

$7 \times 10^{6} \mathrm{~m}^{3}$, respectively. The volume erupted $\left(\sim 80 \times 10^{6} \mathrm{~m}^{3}\right)$ is about three times that indicated by the surface deformation. $0.2 \mathrm{Tg}$ of $\mathrm{SO}_{2}$ was released in the troposphere (Carboni et al., 2015). Four years before this, in October 2004, an intruding dyke at Dallol on the extreme northern tip of the Erta Ale segment, $50 \mathrm{~km}$ NNW of Alu-Dalafilla, was revealed by InSAR (Nobile et al., 2012). This dyke was $9 \mathrm{~km}$ long, striking $155^{\circ}$ (c.f. $167^{\circ}$ Alu-Dalafilla), $\sim 2-6 \mathrm{~km}$-deep, with an intruded volume of about $60 \times 10^{6} \mathrm{~m}^{3}$.

\section{Erta Ale (2010)}

A lava lake has been observed over decades at one of two pit craters within the summit caldera of this rift axis shield volcano. The northern pit crater lies at the junction of two rift zones oriented NNW (the rift axis trend) and N (Acocella, 2006). Occasionally, lava levels rise to overflow the pits producing lava flows on the main crater floor. The best-documented example of which occurred in 2010 , when about $6 \times 10^{6} \mathrm{~m}^{3}$ of lava was extruded over a few days (Field et al., 2012). We ignore earlier episodes of overflow.

\section{Dabbahu-Manda Hararo (2005-2010)}

This was easily the largest known volcano-tectonic event in the EARS. It involved the formation of a near $100 \mathrm{~km}$-long deformation field, with a graben flanked by symmetrical uplifts and evidence of magma transport through two central volcanoes at its northern end (Wright et al., 2006). The 2005 dyke emplaced below the graben had a volume of $1.5-2.0 \mathrm{~km}^{3}$. A small explosion of rhyolitic tephra and a lava occurred on a $400 \mathrm{~m}$-long fissure at Da'ure' at the northernmost end of the dyke (Ayalew et al., 2006). The small central volcano Gabho, adjacent to this site, had inflated by $12 \mathrm{~cm}$ in the year before the eruption from a shallow source. This probably involved the basalt magma that in 2005 intersected a shallow body of rhyolite. Over the next 5 years there were 12 more dykes with an average length of $9.5 \mathrm{~km}$, width of $1.7 \mathrm{~m}$, depth range of $0-10 \mathrm{~km}$ and volume of $90 \times$ $10^{6} \mathrm{~m}^{3}$ (Hamling et al., 2009; Ferguson et al., 2010). These were all fed by a magma source below the middle of the rift segment that deflated as rising magma intruded (Grandin et al., 2009). Of the 12 new pulses of magma, three made it to the surface, in August 2007, June 2009, and May 2010 during brief basaltic fissure eruptions (Ferguson et al., 2010; Barnie et al., 2015). Sulfur dioxide plumes were consistent with volatile loss solely from the extruded volumes of lava.

\section{Oldoinyo Lengai (2007-2008)}

A combined dyke and fault motion episode was observed by InSAR at the southern end of the Natron rift segment over several months in 2007-2008 (Baer et al., 2008; Calais et al., 2008). No magma reached the surface above the initial $8 \mathrm{~km}$ long, NE-trending dyke and fault underneath the southern end of the Gelai volcano and the relationship to volcanic activity at Oldoinyo Lengai was inferential. Modeling of later InSAR data by Biggs et al. (2009, 2013a), however, made a convincing deformation link to Oldoinyo Lengai that involved a $4 \mathrm{~km}$-long, E-oriented dyke intrusion and a central point source of deflation. Stress calculations suggest that the initial 

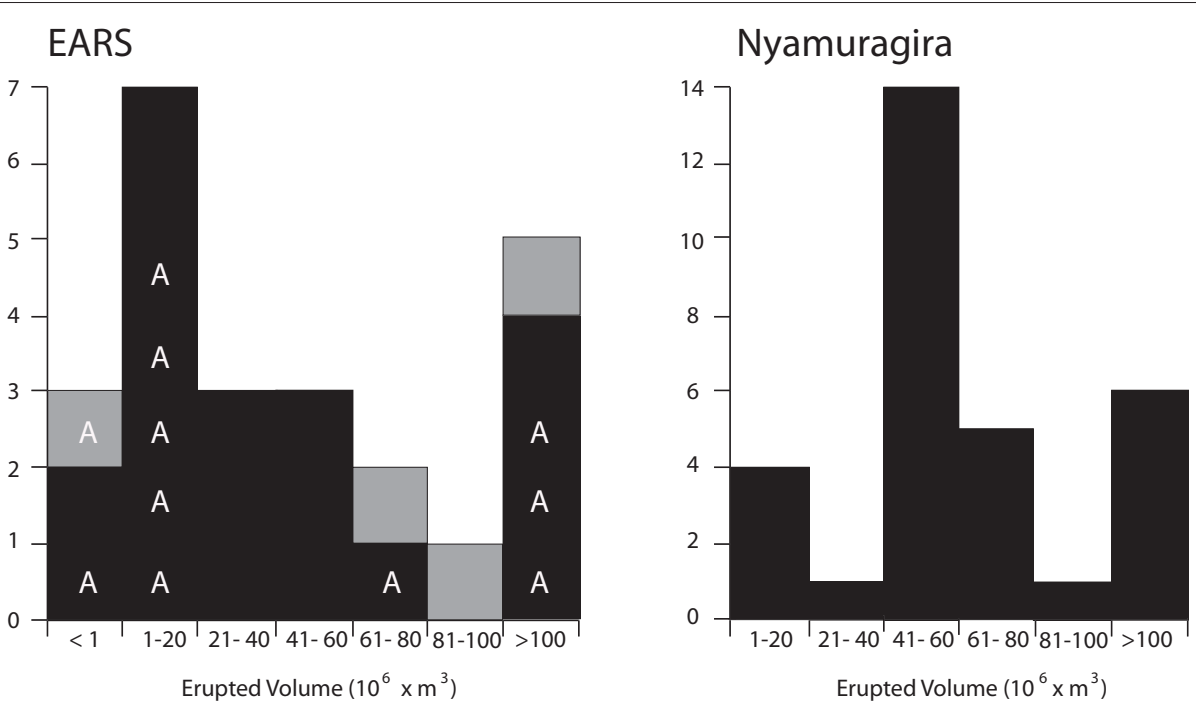

FIGURE 4 | Histograms of the number of eruptions by interval $\left(20 \times 10^{6} \mathrm{~m}^{3}\right)$ of volume erupted, for EARS (left) and Nyamuragira (right) between 1902 and 2012. Black represents basalt extrusion and gray represents more silicic lava. All four eruption episodes at DMH are shown in the EARS plot. Eruptions in Afar are denoted by the letter $\mathrm{A}$. Note the factor of 2 difference in the scales depicting the number of eruptions.

rift event could have unclamped the magma chamber beneath Oldoinyo Lengai, leading to bubble exsolution of the nephelinite magma at relatively shallow $(\sim 3 \mathrm{~km})$ depths and a series of explosive eruptions producing at least $10-20 \times 10^{6} \mathrm{~m}^{3}$ of tephra. These explosions involved mixtures of nephelinite and natrocarbonatite magmas, probably involving a deep pulse of silicate magma. Major explosive events involving both magma types have occurred in 1916-1917, 1940-1941, 1966-1967, and 2007-2008 (Kervyn et al., 2010).

\section{Nyiragongo (2002)}

This eruption involved the formation of a southward propagating fissure, draining the summit lava lake to feed a rapidly advancing lava flow that entered Lake Kivu (Komorowski et al., 2002; Tedesco et al., 2007). In addition, rift-wide extension, detected by InSAR, together with seismicity was interpreted in terms of a southward propagating shallow dyke and a deeper one, $40 \mathrm{~km}$ long (Wauthier et al., 2012). Wadge and Burt (2011) argued that a very similar N-S dyke-driven eruption occurred during the only other historical flank eruption in 1977. Like the lava lake at Erta Ale, the Nyiragongo lava lake also lies at the junction of two rift zones diverging by $20^{\circ}$, both active historically: one oriented $\mathrm{N}$ (1977 and 2002) and one oriented NNW (1977).

\section{Nyamuragira (2011-2012)}

This is Africa's most productive volcano having had over 30 major eruptions in the last 100 years alone (Smets et al., 2010). These eruptions often involved dyke/fissure systems propagating downslope from a caldera above a chamber at $\sim 3-4 \mathrm{~km}$ depth (Toombs and Wadge, 2012; Wauthier et al., 2013) to effusive vents on the flanks. The 2011-2012 eruption was particularly voluminous and long-lived $\left(305 \times 10^{6} \mathrm{~m}^{3} ; 143\right.$ days $)$ from a NE-oriented fissure $12 \mathrm{~km}$ from the caldera (Albino et al., 2015).
In June 2014, a new lava lake was established in the east pit crater of the caldera (Coppola et al., 2016).

The occurrence of these events within the 2002-2011 interval suggests that either the EARS as a whole experienced an episode of increased extensional susceptibility, or that there have been more of these events in the past that have been missed. Certainly, the Oldoinyo Lengai and Dabbahu Manda-Hararo events left relatively little surface volcanic record given the scale of the events. Biggs et al. (2013b) also showed that recent seismic swarms at Lake Magadi and Lake Manyara had no accompanying deformation associated with a dyke. Dyke events with no magma extrusion almost certainly have been missed over the last 200 years.

\section{Historically-Recorded Eruptions (1800-2002) \\ Dubbi (1861)}

This was a globally significant eruption producing a trachyte ash cloud and perhaps pyroclastic density currents, followed after about 2 days by effusion of basaltic lava flows for perhaps 5 months (Wiart and Oppenheimer, 2000a; Wiart et al., 2000). The total erupted volume was estimated at between 1.2 and $3.6 \mathrm{~km}^{3}$, depending on interpretation of the age of the lava flows. There was no caldera formation but the initial Plinian column tapped a crustal reservoir of evolved magma. The chain of volcanoes of which Dubbi is the most northerly is the Nabro Volcanic Range (NVR), which is oriented NNE and is distinct from the family of NW-trending rift structures elsewhere in north and central Afar.

\section{Ardoukoba (1978)}

This small eruption occurred on the NW-oriented AsalGhoubbet Rift, the landward extension of the Gulf of Aden 


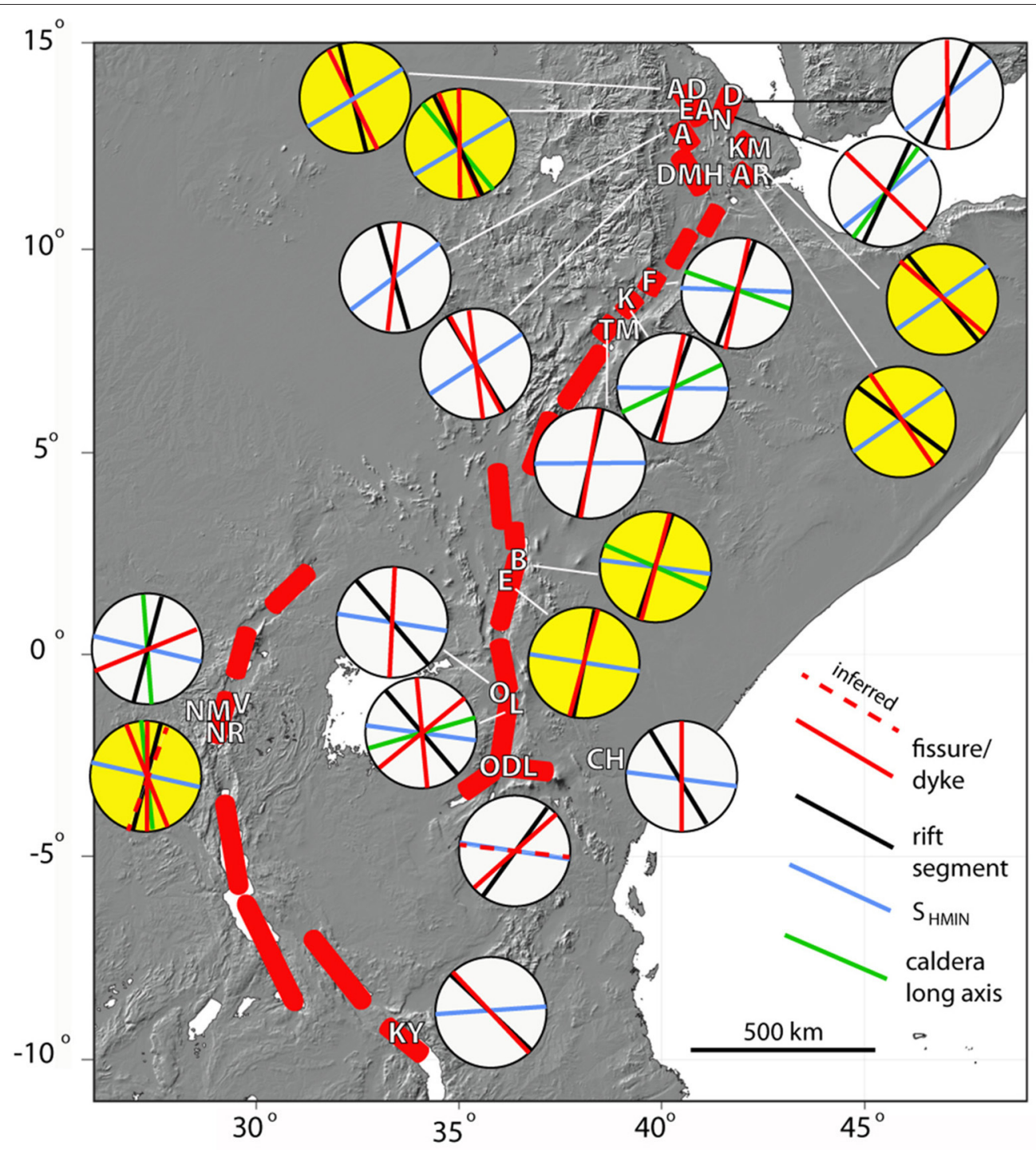

FIGURE 5 | Map of orientation elements in the EARS (Table 2). The red shapes are rift segments with the locations of historical eruptions denoted by their abbreviated names in white (Table 1). For each volcano the orientation of the most recent eruptive fissures, rift segment, $\mathrm{S}_{\mathrm{HMIN}}$ and the long axis of the caldera are shown as diameters of a circle. Red dashed lines indicate inferred dykes. The yellow highlighted volcanoes are those that satisfy the criterion that both $\alpha$ and $\phi>70^{\circ}$ and are "orthogonal" (see Figure 8).

spreading ridge. Basalt lava was extruded from the northwestern end of the rift axis over 7 days (Allard et al., 1979) and fissuring also extended SE beneath the Gulf of Ghoubbet. The central volcano, Fieale, between Asal and Ghoubbet, marks the main source of mantle magma supply (Doubre et al., 2007). Two dykes were formed: the $4.5 \mathrm{~km}$ long, $\sim 2 \mathrm{~m}$ opening Asal dyke beneath Ardoukoba and the $8 \mathrm{~km}$ long, $\sim 3 \mathrm{~m}$ opening Ghoubbet dyke (Tarantola et al., 1979). For 8 years following the eruption, the rift continued to open magmatically with seismicity increasing as opening decreased after 1986 (Doubre et al., 2007). Doubre and Peltzer (2007) considered the Asal-Ghoubbet Rift to be controlled both by the far field plate stress and a locally overpressured magmatic system.

\section{Kammourta (1928)}

Like the Ardoukoba eruption this was a small volume basaltic eruption in an axial fissure setting accompanied by strong seismicity, though details are sparse. The main vent was at the southeastern end of a short line of cinder cones. The accompanying seismic crisis lasted about 1 month and produced surface deformation several kilometers to the south (Audin et al., 1990), suggesting a longer dyke fed the eruption, perhaps similar to Ardoukoba. The Kammourta vent occurred near the southeastern end of the Manda-Inakir Rift, which is connected to the equivalent position on the Asal-Ghoubbet Rift about $50 \mathrm{~km}$ to the south by a zone of closely spaced left-lateral strike slip faults, the Mak'Arrassou, marking the southwest boundary 


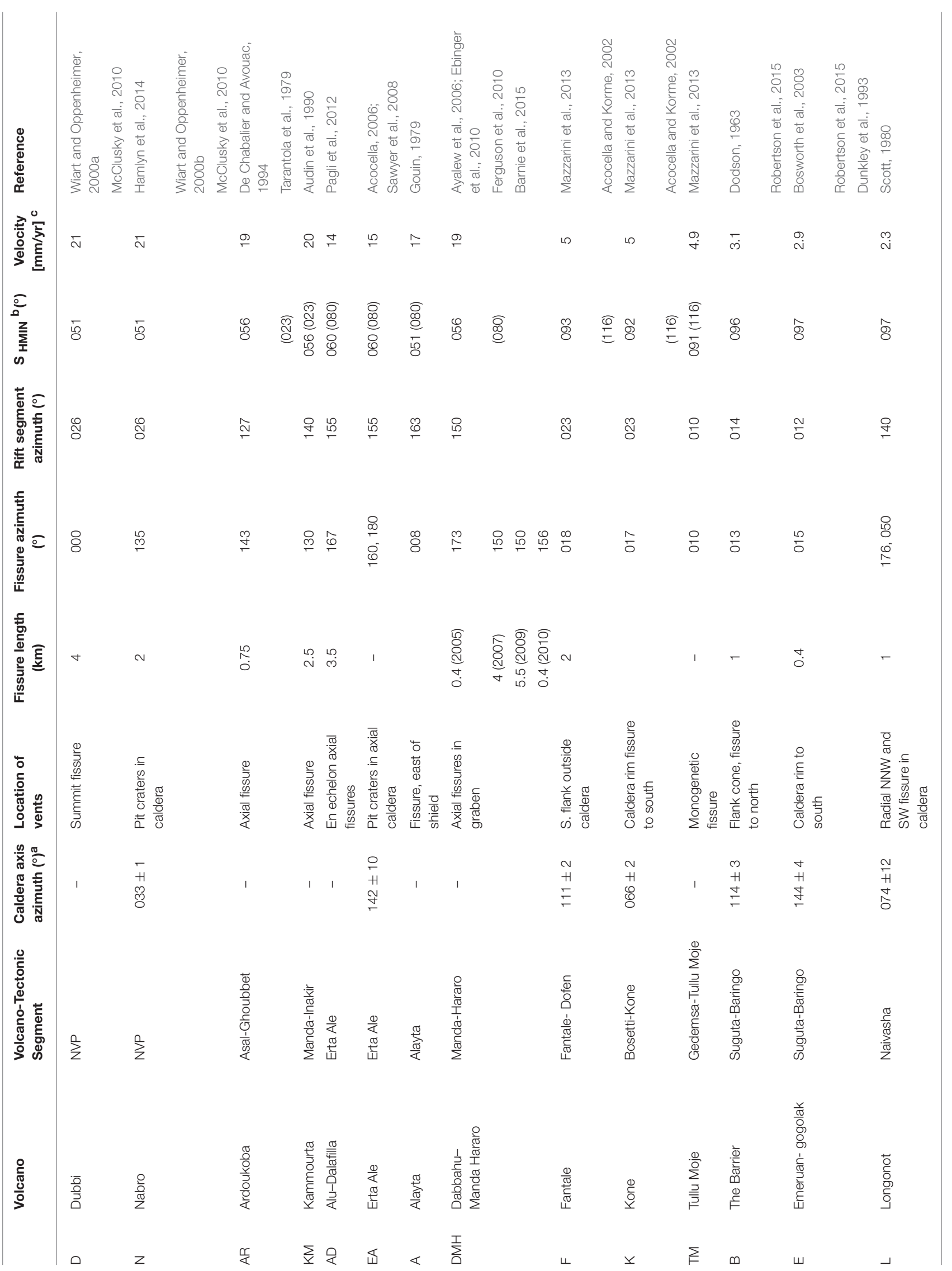




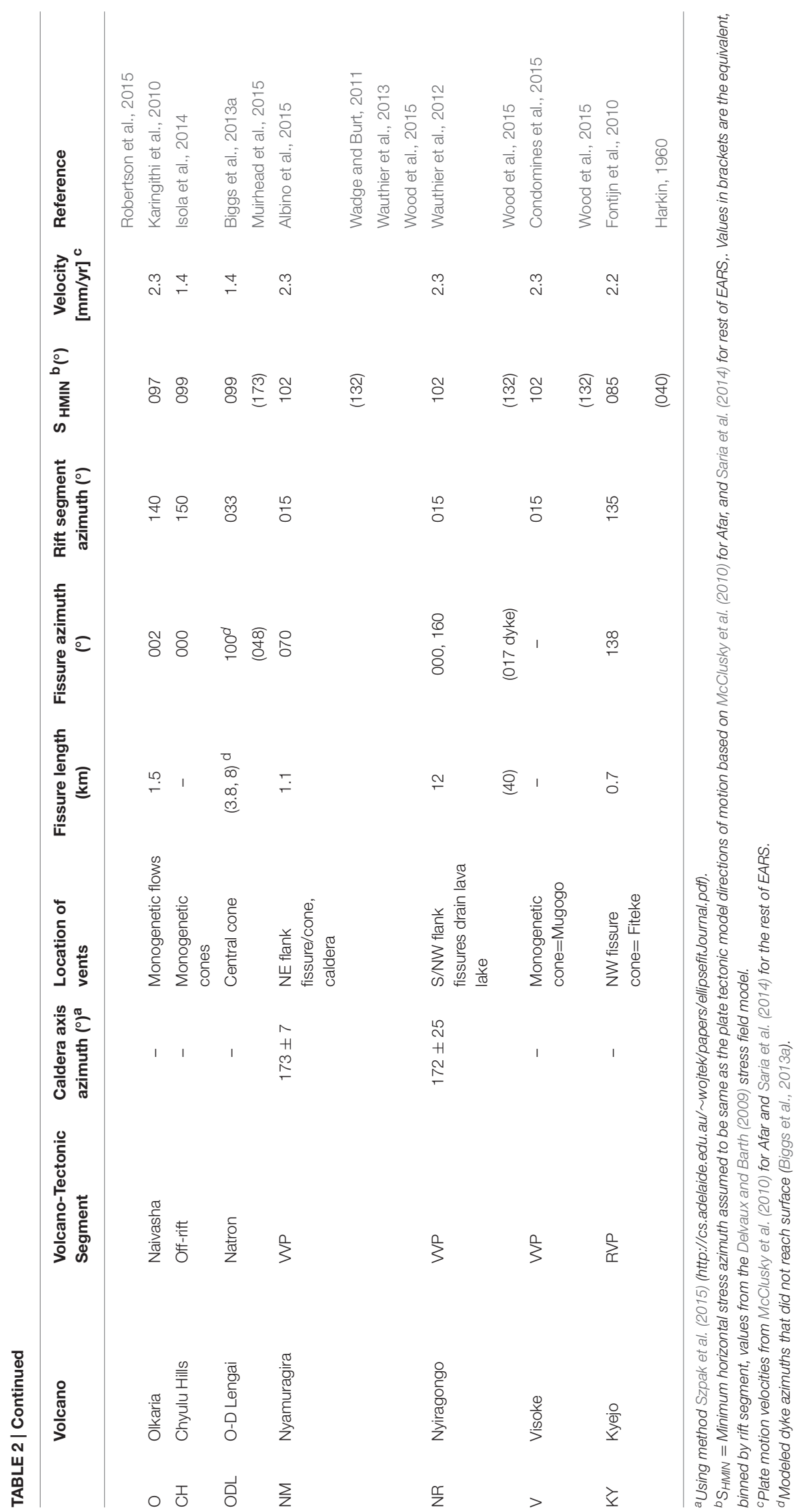




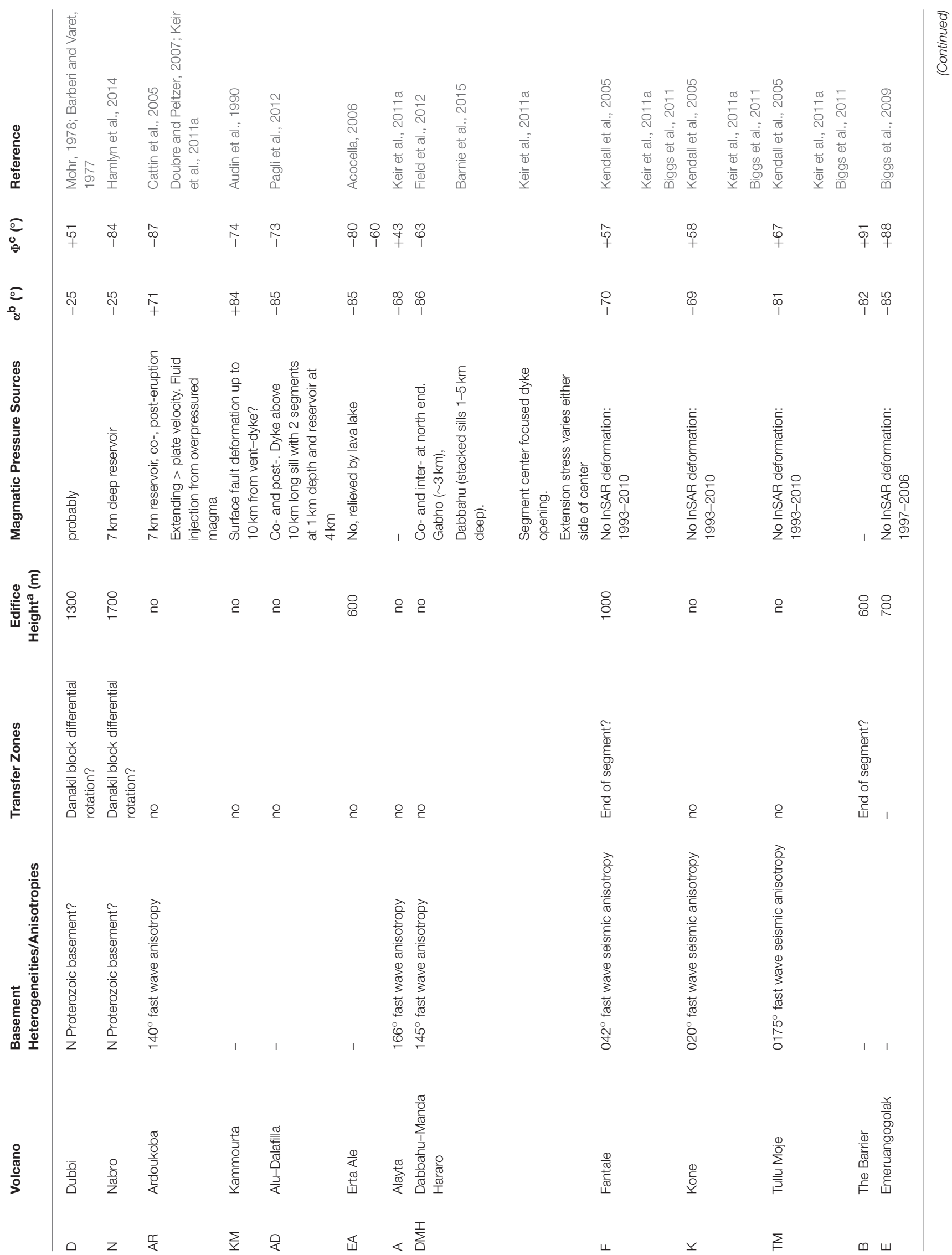




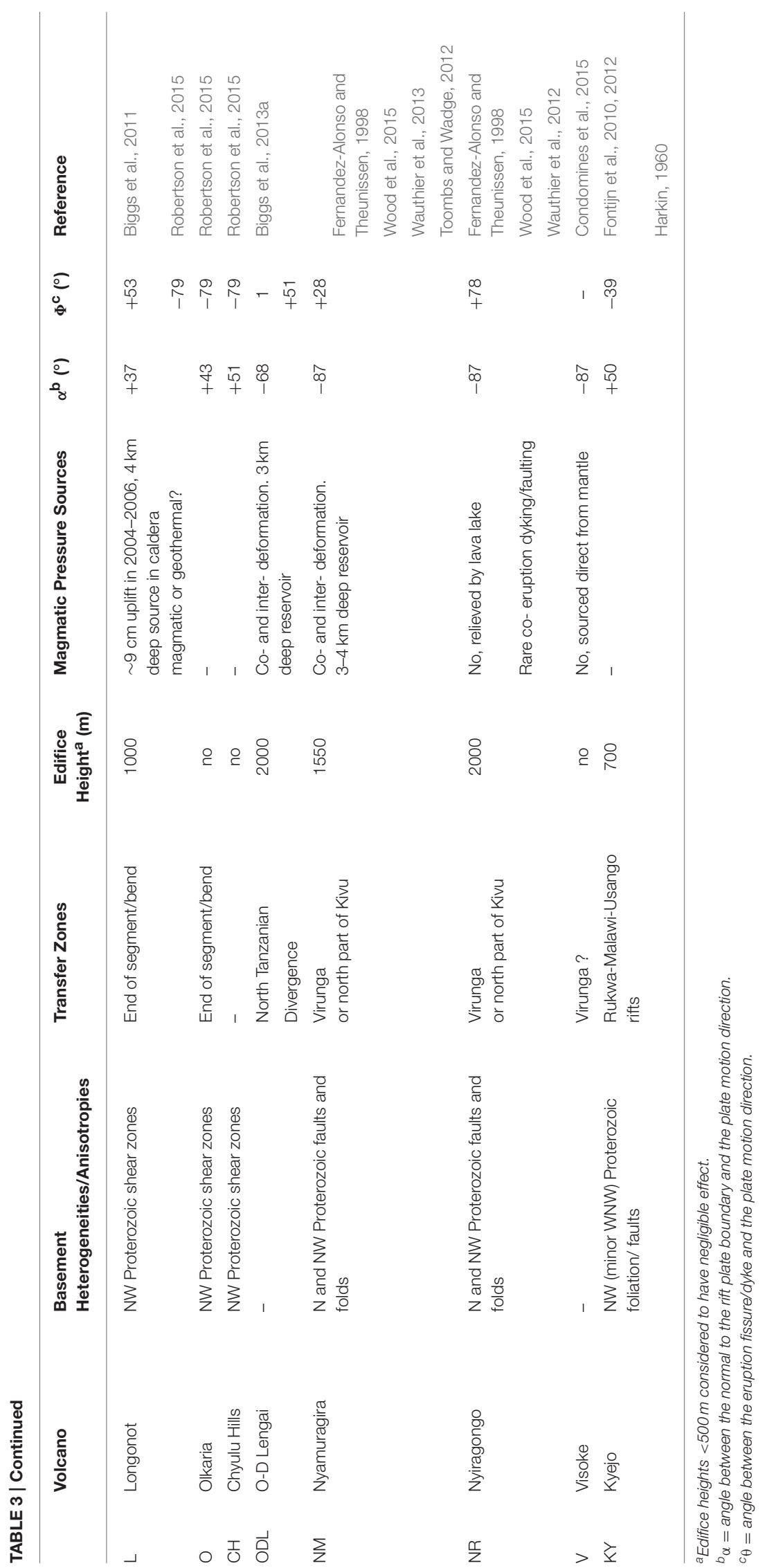


of the Danakil Block (Vellutini, 1990), and perhaps caused by counter-clockwise rotation of it.

\section{Alayta (1906-1907)}

A significant eruption with considerable felt seismicity was recognized in 1906 and 1907 from observers about $200 \mathrm{~km}$ to the east, who mistakenly attributed it to the Afdera volcano (Gouin, 1979). Reports suggest it may have occurred between March 1906 and August 1907 (Gouin, 1979). Its true location among the fissure-fed flow fields east of the Alayta shield was confirmed by Barberi et al. (1970). The lava flow emitted by the eruption has not been identified for certain, but satellite images show a large, bifurcating lava flow field with one arm to the east and the other to the northeast and source vents (at $13^{\circ} 00^{\prime} \mathrm{N} 40^{\circ} 41^{\prime} \mathrm{E}$ ) and a source fissure apparently oriented N (CNR-CNRS, 1973). We take this to be the product of the 1906-1907 eruption. Another reported eruption in 1915 has no useful information.

\section{Fantale ( 1810)}

This silicic, composite volcano mainly comprises rhyolite tuffs and lava domes and has a summit caldera. In about 1810 (Harris, 1844) there was a basaltic eruption, low on the southern flank with a chain of cones oriented NNE, parallel to the Wonji Fault Belt (Acocella et al., 2002). The lava flow extended south to Lake Metahara (Gibson, 1974).

\section{Kone ( 1820)}

Kone or Gariboldi is a complex of silicic calderas and basaltic cinder cones, similar to Fantale $30 \mathrm{~km}$ to the NE. A fissure about $2 \mathrm{~km}$ long trending NNE at the junction of the two most recent calderas was the source of basaltic lava flows in 1820 (Cole, 1969).

\section{Tullu Moje (1900)}

Tullu Moje comprises a widely distributed field of vents. Two comendite lava flows, termed Giano (Bizouard and Di Paula, 1979), were erupted from a fissure oriented $010^{\circ}$ on the rift floor southeast of Lake Koka. A "pitchstone" ashfall was reported to have destroyed crops in 1900 (Gouin, 1979, p. 105). Another eruption is also reported from $1775 \pm 25$ years. The Giano flows are assumed to be the product of the 1900 eruption.

\section{The Barrier (1895)}

Following its discovery in 1888 , this volcano complex which straddles the rift at the southern end of Lake Turkana has been described, rather confusingly, as in eruption several times (1888, 1895, 1897, 1917, 1921; Cavendish, 1897; Champion, 1935), involving two scoria cones (Teleki's cone to the north and Andrew's cone to the south of the main edifice; Dunkley et al., 1993). Dodson (1963) mapped the last, mugearitic, lava flow from Teleki's cone, presumed to have been erupted in 1895 [paleomagnetic dating is consistent with this (Skinner et al., 1975)]. It is possible that basaltic flows from Andrew's cone are also post-1800, but there is no good evidence yet.

\section{Emuruangogolak (1910)}

This shield volcano has a summit caldera and flank trachyte and basalt lava flows. The latest lava flow is of comendite, $\sim 4 \mathrm{~km}$ long and dated magnetically as $1910 \pm 50$ years (Skinner et al., 1975).
The vent sits on a NNE-trending fissure at a break in slope on the southern side of the volcano (Dunkley et al., 1993).

\section{Longonot ( 1863)}

Two trachyte lava flows were extruded on the southwest and northern flanks of Longonot. Their feeding fissures are radial with respect to the summit pit crater and the flows are in a similar state of preservation (Scott, 1980). Thompson and Dodson (1963) quote L.S.B. Leakey as having spoken to a tribesman who claimed to have witnessed activity at Longonot in the mid-1800s. It is presumed that these two lava flows were both produced then, around 1863.

\section{Olkaria ( 1800)}

This is a complex of peralkaline rhyolite lava flows erupted from at least 13 centers over the last 20 kyear (Marshall et al., 2009). The youngest of these is the Ololbutnot flow which has a $\mathrm{C}^{14}$ date of $180 \pm 50$ year BP (1720-1820) derived from carbonized wood associated with a pumice flow.

\section{Chyulu Hills (1865)}

This monogenetic field of vents and scoria cones extends for over $100 \mathrm{~km}$ following a northwest trend, well to the east of the rift in southern Kenya. The younger vents are in the south and the youngest are the Shaitani and Chaimu cinder cones and basanite lava flows which were emplaced in 1865 (Spath et al., 2000; Scoon, 2015). The fissures feeding the cones of both these have a $\mathrm{N}$ trend.

\section{Visoke (1957)}

A 2-day eruption $10 \mathrm{~km}$ north of Visoke volcano in the VVP produced a $1 \mathrm{~km}$-long lava flow and a $40 \mathrm{~m}$-high scoria cone. There is no discernible eruptive fissure but the 1957 eruption was not located on the prominent NE oriented fissure zone that runs between Visoke and Sabinyo volcanoes. This is the only known historical eruption of an olivine melilitite lava anywhere. Its unusual geochemistry means that it is not related to Visoke volcano, nor to the other Virunga volcanoes, but rather was directly sourced from the mantle as a very early stage foiditic magma, such as fed the early Nyamuragira volcano (Condomines et al., 2015).

\section{Kyejo (1800)}

The only historical eruption from the Rungwe Volcanic Province (RVP) comprised a tephrite lava flow from a NW-oriented fissure on the northern slopes of the Kyejo central volcano. The Fiteko cone appears to be the source of the most recent flow. The age of the eruption is based on oral tradition (Harkin, 1960). Whilst there is some uncertainty about the lava flow at source (Fontijn et al., 2012) the area covered by the flow is distinct.

\section{DISCUSSION}

\section{Eruption Characteristics}

Despite an extensive geological record of explosive volcanism in EARS, in the form of large calderas and widespread tephra layers (e.g., Hutchison et al., 2015), there have only been two historical eruptions with VEI $\geq 4$ : at Dubbi in 1861 and Nabro in 2011. Both were explosive in their initial 
stages, generating large, but unmeasured silicic tephra deposits, followed by large volume basaltic lava flows, suggesting that prior to eruption, batches of basaltic magma intersected highlevel bodies of trachyte magma. Oldoinyo Lengai also displays explosive behavior, and although the 2007-2008 eruption was VEI3, it was more protracted than at Dubbi or Nabro, lasting several months. Like Dubbi and Nabro this involved rising mafic magma from depth intersecting a shallow reservoir with magma of a more evolved composition. Similar explosive eruptions occurred in 1916-1917, 1940-1941, and 1966-1967, but this 20-40-year cyclicity of magma mixing events is not seen elsewhere in the EARS. Low intensity explosivity, involving ash fall and column collapse, is thought to have accompanied at least two of the three main cases of rhyolitic lava flow in the EARS, with reports of "pitchstone" ashfall from the 1900 eruption of Tullu Moje, and the pumice flow associated with the Ololbutnot rhyolite lava flow at Olkaria.

Historically, effusive eruptions have been more common than explosive eruptions in the EARS and the volumes of individual lava flows range over four orders of magnitude, from $10^{5} \mathrm{~m}^{3}$ for the small eruptions associated with the 20052010 dyke intrusion at $\mathrm{DMH}$ to $10^{9} \mathrm{~m}^{3}$ for the 1861 lava flow at Dubbi. The Dubbi lava flow, although of somewhat uncertain volume, is of comparable magnitude to that of the combined intruded dyke volume of the DMH 2005-2010 event. A low-volume lava flow from the 1957 Visoke eruption, seems to have been a rare, directly mantle-fed, monogenetic event. Between these two extremes, the volume distribution is bimodal as plotted in Figure 4. The lower value mode is the $1-20 \times 10^{6} \mathrm{~m}^{3}$ bin and the upper mode bin is unbounded and thus represents the high-volume tail of the distribution. Eruptions in Afar contribute disproportionately to the lower volume counts, suggesting that the bimodal distribution may be a result of recording bias: historical records only include the largest volume flows, while the more complete geophysical record only extends for a few decades and is dominated by the recent small flows in Afar. The equivalent plot for the volumes of the 31 flank eruptions of Nyamuragira from 1901 to 2012 is also shown in Figure 4 (note that the 2011-2012 volume has been used in both plots). The mode at Nyamuragira is at the 41-60 × $10^{6} \mathrm{~m}^{3} \mathrm{bin}$, five-times the value for the EARS mode, and there are no silicic or very low volume eruptions.

Of the 21 eruptions, we know the durations of 15 (Table 1). The distribution of durations is strongly skewed, with 10 of the eruptions lasting less than 20 days (and 8 lasting less than 5 days). Four eruptions lasted 150 or more days. Three of the long-duration eruptions: Dubbi (150 days), Alayta (500 days), Nyamuragira (150 days) also had large extruded volumes $\left(>300 \times 10^{6}, \mathrm{~m}^{3}\right)$. Eruption-averaged extrusion rates range from about 1 to $270 \mathrm{~m}^{3} \mathrm{~s}^{-1}$, typical of volcanoes elsewhere (Harris et al., 2007). Nyamuragira is the only volcano with enough measured eruptions to estimate time-variable extrusion rates: $0.47 \mathrm{~m}^{3} \mathrm{~s}^{-1}$ before 1980 and $1.13 \mathrm{~m}^{3} \mathrm{~s}^{-1}$ during 1980-2002. This marked, long-term change in surface supply was probably caused by the 1977 Nyiragongo volcano-tectonic event changing the stress field beneath its neighboring volcano (Wadge and Burt, 2011).

The apparent increase in volcano-tectonic activity in the EARS between 2002 and 2011 may have been due to a plate boundary-wide adjustment of stresses, but could also be the result of reporting bias due to the increased use of InSAR. The lack of equivalent events in the 5 years since 2011 suggests the former. Pagli et al. (2014) demonstrate that the DMH dyke intrusion altered the strain field for at least 5 years after the event, over distances of $200 \mathrm{~km}$, including the area around several other volcanic systems in Afar. There is little evidence for an increase in activity elsewhere in the EARS; Oldoinyo Lengai and Nyamuragira erupt frequently and the 2007-2008 eruption at Oldoinyo Lengai fits the established pattern of 20-40 year periodicity in explosive episodes. Biggs et al. (2016) used observations from the Kenyan Rift to show that even small changes in strain associated with minor unrest can affect multiple reservoirs beneath individual volcanoes, but typically do not extend to neighboring volcanoes at distances $>10 \mathrm{~km}$. The hypothesis could be tested by (1) improving the historical record by dating the numerous small-volume lava flows found at volcanoes in the EARS (e.g., Hutchison et al., 2015) and (2) constructing 3-D velocity fields from InSAR and GPS (e.g., Pagli et al., 2014).

\section{Subsurface Magmatic Systems}

Many of the volcanoes of the EARS are known to be deforming and/or seismically active (Table 3), but the link to eruption is statistically weak (Biggs et al., 2014) and it is unclear whether the source of the unrest is magmatic or hydrothermal. For the deformation events associated with eruptions, shallow $(<5 \mathrm{~km}$ deep) dykes and sills dominate the co-eruption motion signals: Ardoukoba in 1978, Alu-Dalafilla in 2008, Dabbahu-Manda Hararo in 2005, 2007, 2009, 2010, Oldoinyo Lengai in 20072008, Nyamuragira in 2012 and Nyiragongo in 2002. Where model inversion of InSAR data associated with the eruption calls for deeper magmatic sources below the shallow dykes and sills (Segall, 2010), the data have not warranted more complexity than a Mogi point source: Nabro in 2011 (7 km deep), AluDalafilla in 2008 (4 km), Dabbahu-Manda Hararo from 2005 to $2010(10 \mathrm{~km})$, Nyamuragira from 1996 to $2012(4 \mathrm{~km})$ (Wauthier et al., 2013). For unrest signals not associated with eruption, the source is one or more shallow reservoirs $(<8 \mathrm{~km})$ with lateral interactions limited to distances of $<10 \mathrm{~km}$ (Biggs et al., 2016). The deformation patterns are typically radially symmetric, so we have no good evidence for magma reservoir shapes (e.g., ellipsoidal) that can be used to infer the relationship to the horizontal differential stress field.

The ratio of intruded to extruded magma can give insight into the subsurface rheology and stress field. However, for many of the older historical eruptions, no geodetic data was available, and only the extrusive component of the total magma budget of the event is known, while for some of the recent dyke emplacement events, 9 of the 13 in the 2005-2010 DMH episode, there was no extrusive component. Where available, intrusion/extrusion ratios are in the range $4-15$ (Table 1 ), the exception being the small 2010 extrusive volume at DMH which was dwarfed by a 
much larger dyke to give an intrusion/extrusion ratio of 352. Any increase in the external stress normal to a magma-filled dyke will tend to close it and force magma to the surface, decreasing the ratio. The largest volume lava flow erupted at or close to the axial rift was at Alayta, where the high obliquity of the dyke $\left(\phi=43^{\circ}\right)$ may have been sufficient to force a greater proportion of magma from a large parental dyke to the surface than elsewhere.

\section{Orientations of Eruptive Fissures and Dykes}

The orientations of the historical eruptive fissures or dykes are shown in Figure 5, along with the orientation of the rift segment, the current direction of plate motion, $\mathrm{S}_{\mathrm{HMIN}}$ and the long axis of the caldera. The regional pattern of historical fissuring in Afar is shown in Figure 6. The majority of the recent eruptive fissures and dykes in Afar (Alu-Dalafilla, Erta Ale, and DMH, and Ardoukoba and Kammourta, further east) share a narrow range of orientations around NW to NNW as we would expect for purely extensional regimes. The orientation of the Alayta eruptive fissure is $\mathrm{N}$ and the crustal fabric near Alayta reported in Section Orientation and Influence of Structural Fabric and Anisotropy suggests that Alayta has some degree of oblique structural control. The NVR crosses the Danakil microplate as a $0.26^{\circ}$ trending structure that obliquely links the spreading axes of Afar and the Red Sea (Barberi and Varet, 1977). The NVR may be the locus of local counter-clockwise motion within the Danakil Block (McClusky et al., 2010; Figure 4). The eruptive fissure at Nabro trends NW like the majority of Afar volcanoes, but the other active NVR volcano, Dubbi, has a N-trending fissure similar to Alayta.

The five eruption sites in the northern parts of the MER and the Kenya Rift show very close alignment between the border faults and recent eruptive fissures, however, in some cases this is oblique to either the long-axis of the caldera (Kone) or the current plate motion (Fantale). In the southern Kenyan Rift (Longonot, Olkaria and off-rift Chyulu Hills), the recent fissures are aligned with the current plate motion direction, but oblique to the rift border faults.

Oldoinyo Lengai shows structural elements at many orientations suggesting a radial stress field. Oldoinyo Lengai sits within the North Tanzanian Divergent Zone, a region of complex tectonic adjustments (Muirhead et al., 2015) and beneath a large edifice. The detection of two, non-erupting, dyke-forming events at different times during the 2007-2008

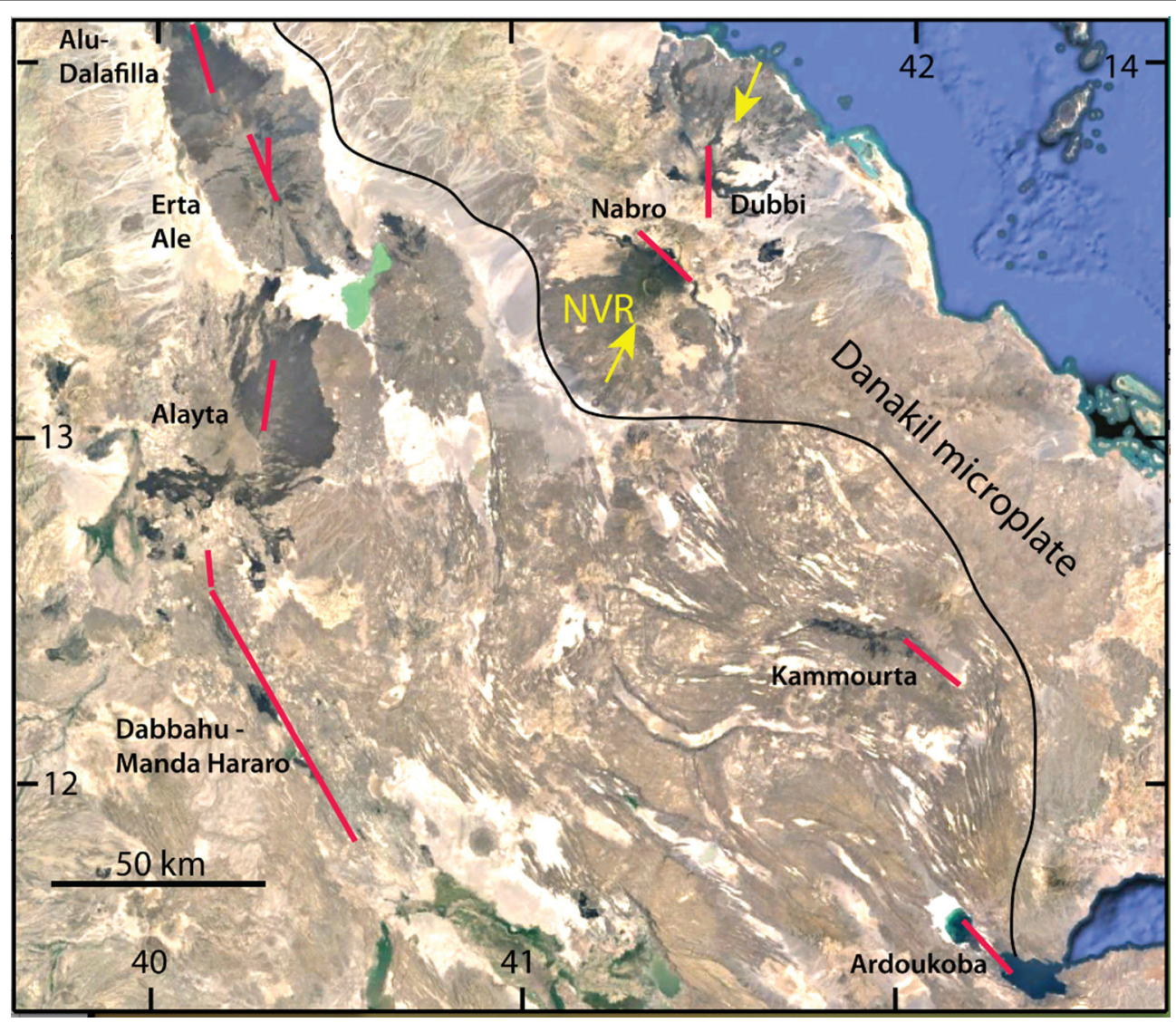

FIGURE 6 | Image map (based on Google Earth) of central Afar showing the locations and orientations of the fissures produced by the historical eruptions (red lines). The lengths of fissures is schematic, particularly for Dabbahu-Manda Hararo which was largely an intrusive event. The yellow arrows indicate the Nabbro Volcanic Range (NVR) which crosses the Danakil microplate whose southwestern margin is shown by the black line. The grid marks are in degrees of latitude and longitude. 
eruptions that are strongly oblique to each other (Biggs et al., 2013a) and multiple radial fissures (Muirhead et al., 2015) indicates that stress is locally variable, with edifice loading and magma pressure sufficient to exceed the regional stress field close to the volcano (Biggs et al., 2013b). These observations are similar to the eruption of Jabal al Tair in 2007, just to the north of our area, which displayed an eruptive dyke perpendicular to the rift direction ( $\mathrm{Xu}$ and Jonsson, 2014).

At Nyiragongo and Nyamuragira, the current plate motion direction is ESE, but the trends of the eruptive fissures are more oblique and variable, from ENE to WNW. Proterozoic $\mathrm{N}$ and NW-oriented basement features may be responsible for the $\mathrm{N}$ and NNW fissure zones, to the south of Nyiragongo and between the two volcanoes respectively (Figure 7). These zones may also be the conduits of stress transfer at the northern end of the Kivu Rift and have played a large role in the historical volcanism. Both volcanoes have large edifices with flank eruptions extending out to over $20 \mathrm{~km}$. Beyond about $7 \mathrm{~km}$ on Nyamuragira the orientation of some fissures curve to rift boundary orientation as would be expected for combined edificetectonic stress fields (Figure 2D). The clear increase in extrusive output of Nyamuragira, following the 1977 volcano-tectonic event at Nyiragongo, was attributed to a change in the local stress field (Wadge and Burt, 2011). After 1977, the NE-trending fissure zone southwest of Nyamuragira became inactive whilst the equivalent ENE-trending zone east of the edifice became active (Figure 7). The cumulative volume erupted within $7 \mathrm{~km}$ of the caldera increased from 210 to $560 \times 10^{6} \mathrm{~m}^{3}$ over periods of 28 (1948-1976) and 25 (1977-2002) years, respectively, whilst the equivalent volume beyond $7 \mathrm{~km}$ distance increased from 211

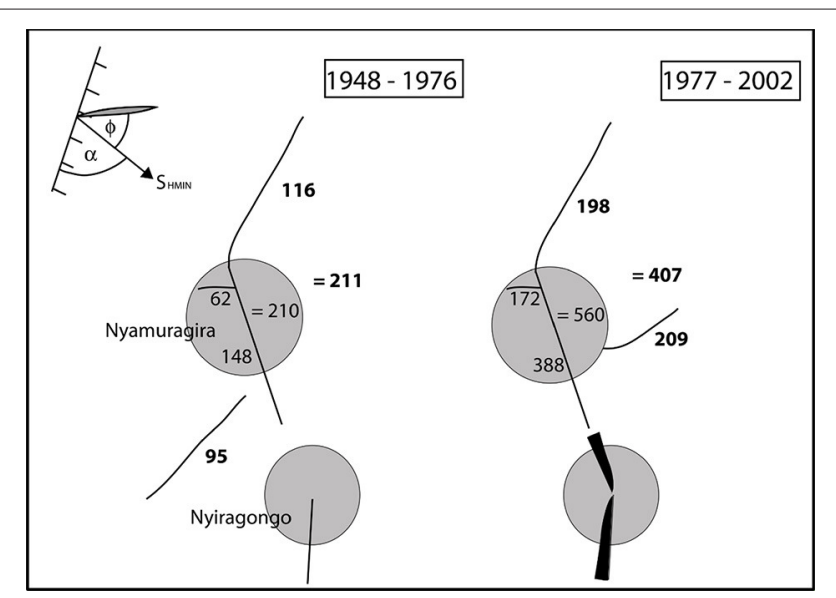

FIGURE 7 | Schematic of the eruptive fissure system of Nyamuragira and output of lava for two periods: 1948-1976 and 1977-2002, separated by the volcano-tectonic event at Nyiragongo volcano in 1977 , shown as the black blade symbol representing a major dyke emplacement. The Nyamuragira gray circle represents a $7 \mathrm{~km}$ radius of edifice stress influence. The numbers associated with each fissure (line segment) are the cumulative volumes $\left(10^{6} \times \mathrm{m}^{3}\right)$ erupted from that fissure zone over that period. The bold numbers are those from eruptions outside the $7 \mathrm{~km}$ radius edifice. In the top left corner is a schematic representation of the geometry of the rift azimuth (ticked line), extension direction $\sigma_{3}$, and the obliquity angles $\alpha$ and $\phi$ for Nyamuragira. to $407 \times 10^{6} \mathrm{~m}^{3}$. We interpret this as an increased tendency for magma to reach the surface, particularly centrally, beneath Nyamuragira following the 1977 event. Although we cannot prove it (e.g., from InSAR measurements), we concur with Wadge and Burt that the intrusive/extrusive ratio was generally higher for eruptions prior to 1977 and a larger proportion of the deep magma supply was diverted to intrusions rather than reaching the surface compared to the behavior in the post-1977 period.

The obliquities of the eruption sites are summarized in Figure 8 in terms of the angular measures $\alpha$ and $\phi$, together with the eruption volumes and edifice heights. There are 7 eruptions that fit the orthogonal model (allowing for up to $20^{\circ}$ error) and sit within the gray quadrant of Figure 8. There is no obvious clustering of values round the oblique and transtension model axes, suggesting that processes other than plate tectonic-derived horizontal stress fields are dominant. Large volume eruptions (the five largest being Dubbi, Nabro, Alayta, Olkaria and Nyamuragira) or eruptions that are longlived (e.g., Oldoinyo Lengai) or with large edifices (Nabro, Nyamuragira, Oldoinyo Lengai) tend to have high obliquity indicating that the tectonic stress field is less dominant in these cases.

In Afar, two NVP volcanoes, Dubbi and Nabro have edifices 1300 and $1700 \mathrm{~m}$ high respectively and both have erupted

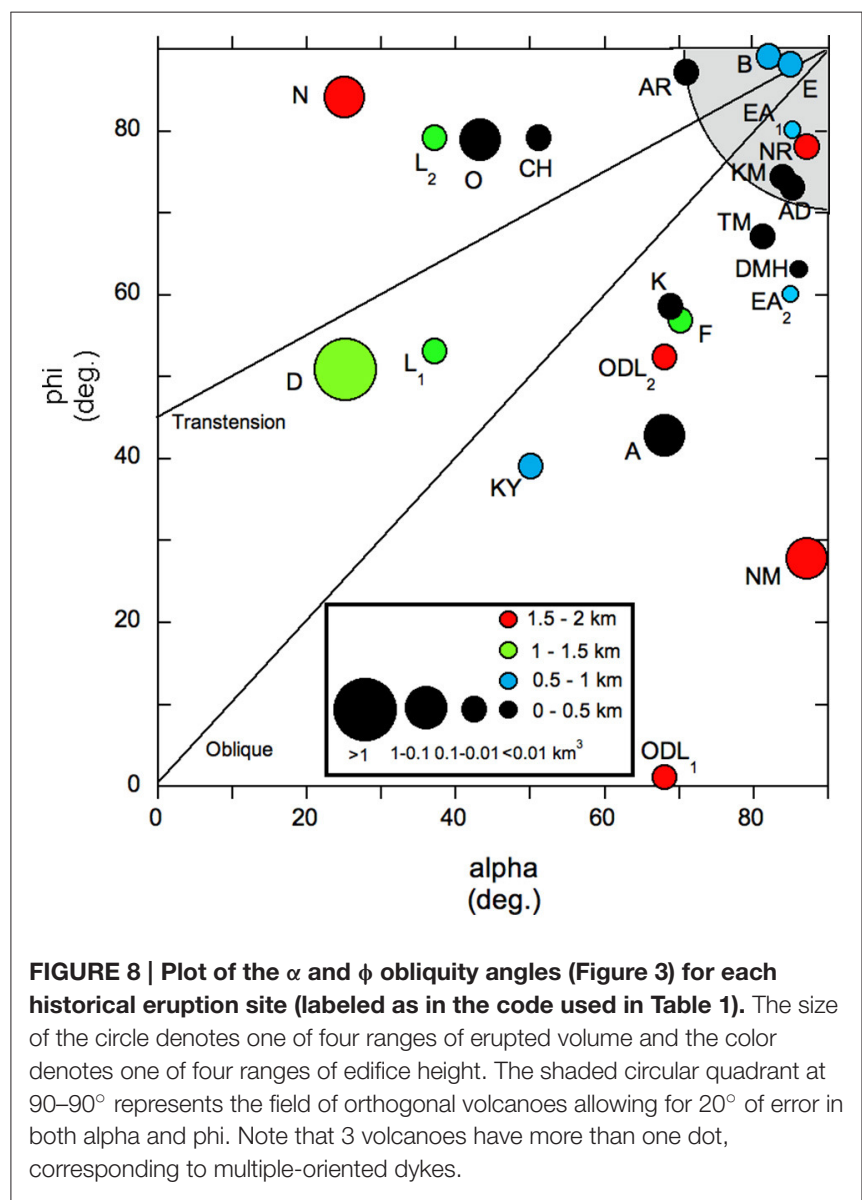




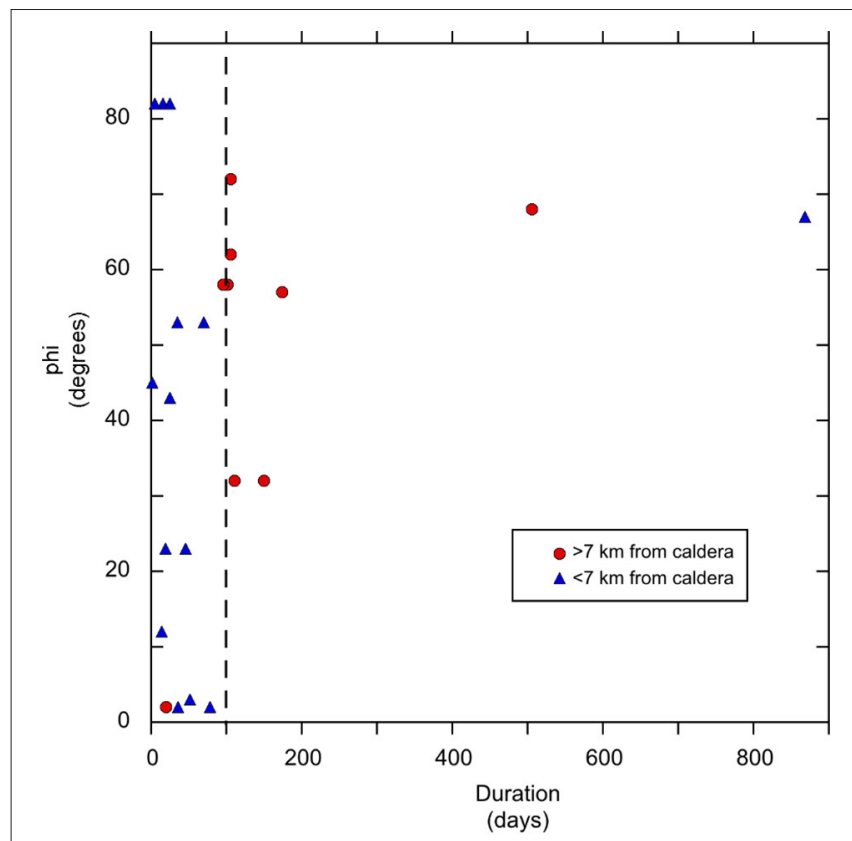

FIGURE 9 | Plot of $\phi$ against duration of eruptions at Nyamuragira for the period 1938-2012. Eruption sites located $<7 \mathrm{~km}$ from the caldera are plotted as blue triangles, $>7 \mathrm{~km}$ as red circles. All but one of the former group have short-lived eruptions ( $<100$ days, dashed black line) and all but one of the latter group have long-lived eruptions.

compositionally zoned magma from central reservoirs, one of the theoretical characteristics of loading-induced development of volcanic systems discussed in Section Magmatic and Volcanic Processes. There is strong loading evidence in the VVP, specifically the observed westward tilting of the Karisimbi edifice that fits a combined asymmetric extension-loading model (Wood et al., 2015).

Figure 9 shows the duration of eruption at Nyamuragira plotted against $\phi$ for those eruptions with known fissure orientations. With one exception, all the long-duration ( $>100$ days) eruptions are located $>7 \mathrm{~km}$ from the caldera (red circles in Figure 9) and mostly have high values of $\phi\left(30-80^{\circ}\right)$ supporting the argument of Wadge and Burt (2011) that eruptions fed by dykes parallel/subparallel to the rift axis were longer-lived and generally had more voluminous lava flows than those fed by rift-orthogonal dykes.

\section{Orientation and Influence of Structural Fabric and Anisotropy}

Structural trends in the Proterozoic basement have been shown to play a role in several of the recent magmatic episodes in the EARS. The Ayelu-Amoissa dyke in the northernmost MER was inferred by Keir et al. (2011b) to owe its ESE strike (Figure 1) to an Oligo-Miocene structure associated with an earlier phase of opening of the Gulf of Aden. The NW-SE oriented field of monogenetic vents at Chyulu Hills, situated about $150 \mathrm{~km}$ to the southeast of the Kenya Rift is another likely example of the influence of the local NNW-trending structural fabric (Isola et al., 2014). In the western arm of the EARS at the VVP, the Proterozoic basement trends are N and NW (Fernandez-Alonso and Theunissen, 1998), both of which seem to play a role in guiding volcanic structures. In the RVP, Kyejo is located close to the junction of the Rukwa, Malawi and Usango rift segments and its historical eruptive fissure is oriented parallel to the dominant NW oriented basement structures (Harkin, 1960; Fontijn et al., 2010).

Seismic anisotropy is an indicator of structural fabric and may reflect a range of structural elements including some which relate to the current stress field (e.g., flow in the mantle, alignment of melt pockets), and others that may not (e.g., pre-existing structural fabrics). In the mantle, the patterns of anisotropy show little spatial variability and are thought to represent alignment of olivine crystals associated with asthenospheric flow. For example, the NE-SW anisotropy beneath Ethiopia is believed to represent flow at depths $>100 \mathrm{~km}$ (Hammond et al., 2014). Shear-wave splitting of teleseismic events show melt-filled cracks at lower crust and upper mantle depths produce anisotropy trending $0.25^{\circ}$ (Kendall et al., 2005). Crustal anisotropy is more variable, and reflects major structural features, for example in Afar, north of the Tendaho-Gobad Discontinuity (TGD), there is a high degree of anisotropy and the fast direction is oriented NNW, but to the south, the anisotropy is more moderate and the fast direction is orientated NNE (Keir et al., 2011a). In Kenya and Tanzania there are regional teleseismic event surveys (e.g., Walker et al., 2004), but only a few shallow crustal seismic anisotropy studies south of Ethiopia, and in the Western Rift, for example in the Ruwenzori segment (Batte et al., 2014). Preliminary teleseismic results from the $\mathrm{VVP} / \mathrm{Kivu}$, indicate a deep northeasterly oriented fabric (Zal et al., 2014).

For most of the volcanoes in Afar, the NNW orientation of the seismic anisotropy is similar to that of the rift axis (e.g., Ardoukoba and DMH). However, at Alayta, which lies close to the seismic station BOOE (Keir et al., 2011a; Figure 3A), the fast anisotropy direction is rotated clockwise relative to the segment axis, with an azimuth of $166^{\circ}$. This is the same sense of rotation as the Alayta 1906-1907 eruption fissure relative to the segment axis and may reflect the obliquity of recent dykes. The closest measurements to recent eruptions in the northern MER (Fantale, Kone, and Tullu Moje) show fast anisotropic directions of NW, NNW, and N, respectively (Keir et al., 2011a). These volcanoes lie on neighboring, en echelon, magmatic segments oriented generally NNW to NW, with superimposed faulting and fissuring oriented NNW, the Wonji Fault Belt. In the southern MER, the geothermally and seismically active, but not eruptive, Aluto and Corbetti volcanoes show strong degrees of anisotropy (Nowacki et al., 2016). Aluto shows a fast shear wave polarization oriented parallel to the WFB, but at Corbetti the splitting trends ESE, parallel to the Wendo-Genet scarp, representing an inherited crustal structure (Figure 1). As yet, there has been no evidence of temporal variation of anisotropy episodes of high-level magma pressurization at any of the EARS volcanoes as seen elsewhere (e.g., Savage et al., 2010), but appropriate experiments have yet to be undertaken.

Inherited structures have been proposed to explain the eccentricity of calderas in the MER and Kenya Rifts (Acocella 
et al., 2002; Robertson et al., 2015). Robertson et al. (2015) argued that NW, trans-rift fault structures in the basement of the Kenya Rift led to elongate reservoirs beneath the southern population of elliptical calderas, including Longonot. Acocella et al. (2002) suggested that E-W inherited structures in the MER controlled the E-W elongated Kone, Fantale, and Gedemsa calderas. In contrast, Bosworth et al. (2003) argued that the caldera eccentricity in the Kenya Rift was due to preferential spalling of wall rocks into magma chambers in the direction of $S_{\text {HMIN }}$. They also made a case for clockwise rotation of the horizontal stress axes of $19^{\circ}$ over $\sim 30$ ka between the formation of The Barrier and Emuruangogolak calderas.

Nine of our historically active volcanoes have calderas (Table 2, Figure 5). They fall into two distinct groups: group 1 (Nabro, Fantale, Kone, The Barrier, Emeruangogolak, Longonot) and, group 2 (Erta Ale, Nyamuragira, Nyiragongo). The group 1 calderas are large and ellipsoidal, consistent with magma reservoir collapse origins. Two of them, Fantale, and The Barrier, have roughly orthogonal geometries with caldera axes elongated within $\pm 15^{\circ}$ of the spreading direction (Table 2). This supports the arguments of Acocella et al. (2002) and Robertson et al. (2015) that although the current stress regime dominates recent eruptive fissures and dykes, it is not the dominant control on caldera orientation or crustal magma storage. The group 2 calderas are smaller and contain persistent or recently active lava lakes in pit craters. The presence of lava lakes at these calderas requires some longevity of magma supply (the lakes are present for tens to hundreds of years), the conditions for maintaining persistent surface storage, a non-dyke (i.e., non-freezing/closing) conduit and a likely simple plumbing system. They also have a low eccentricity, but are elongated approximately parallel to where two fissure zones intersect obliquely $\left[<30^{\circ}\right.$, see e.g., Acocella (2006) for a sketch of Erta Ale]. These observations suggest that crustal stresses have a controlling influence on magmatic processes, independent of buoyancy. Each of the group 2 calderas (in addition to the other long-lived and ephemeral lava lakes such as at Masaya, Kilauea, Ambrym and Erebus) occur at the elbow of a change in the rift orientation $\left(0^{\circ}\right.$ to $150^{\circ}$ at Erta Ale, $0^{\circ}$ to $160^{\circ}$ at Nyiragongo and $150^{\circ}$ to $170^{\circ}$ at Nyamuragira). It is therefore probable that this jag in spreading segments provides the continuous, highly localized low horizontal stresses beneath these calderas, but rapid enough extension rates to maintain magma supply, required to maintain lava lakes. Oppenheimer and Francis (1998) suggested that there is a highly localized ( $<700 \mathrm{~m}$ diameter) magma body at shallow depth (few $\mathrm{km}$ ), consistent with low horizontal stresses. Coppola et al. (2016) make a strong case that the re-instatement of the Nyamuragira lava lake in 2014 was made possible by a change in the volcano's stress field following the very voluminous flank eruption in 2011-2012.

\section{CONCLUSIONS}

We have documented 21 historical eruptions in the EARS over approximately the last 200 years. They have erupted a minimum of about $5 \mathrm{~km}^{3}$ of magma, mainly varieties of basalt. Surface deformation associated with these eruptions has been recorded by InSAR or ground survey in 7 cases. All have involved dykes (sills) and shallow ( $<10 \mathrm{~km}$ depth) magma reservoirs and high intrusive/extrusive ratios (mainly 4-15). Of these 21 eruptions, only 7 of the associated fissures/dykes lie within $20^{\circ}$ of the orthogonal to the plate spreading direction, $(\phi)$, and parallel to the rift axis, the expected geometry for an extensional plate boundary (Table 3, Figure 8). The predominance of nonorthogonal geometries demonstrates that other factors are present in the development of volcanism during the early stages of continental rifting.

We find evidence for four ways to modify the regional plate tectonic stress field beneath these volcanoes: the effects of inherited crustal fabric and anisotropy, the existence of oblique structures in transfer zones between rift segments, crustal loading by large volcanic edifices and the pressures exerted by magma stored and transported within the crust.

Shear wave-splitting studies of crustal and mantle anisotropies, in Afar and MER show that sharp discontinuities (at the $10 \mathrm{~km}+$ scale) in orientation and magnitude in the stress field must exist, particularly across structural boundaries. Current evidence points to dykes and aligned melt enclaves as being responsible for variable anisotropy (Keir et al., 2015). The evidence for crustal heterogeneities in the form of inherited faults and other old structures is clear throughout the rift; NW structures (with $\mathrm{N}$ and WNW variants) that formed in Proterozoic crust dominate in both arms of the EARS. Examples include the Ayelu-Amoissa (2000) dyke event in southern Afar which followed a rift-orthogonal trend (Keir et al., 2011b) and the NW-trending Chyulu Hills monogentic field of volcanoes that runs oblique to the Kenyan Rift. Nonorthogonal crustal extension is accommodated in transfer zones between segments, which may re-activate existing basement faults or generate new ones. The stress field in the transfer zones is complex and not aligned with the current plate motion meaning the resulting volcanism typically has highly oblique elements. Examples include Oldoinyo Lengai in the NTDZ and Nyamuragira at the northern end of the Kivu rift segment.

The stress fields associated with tall edifices play a strong role in the EARS. Based on the following characteristics: radial dykes (curving with distance from the volcano and at shallow depth to meet the regional stress field, Figure 2D; c.f. Roman and Jaupart, 2014), a central magma reservoir, and explosive silicic magmas, mingling with mafic magma, we recognize 6 volcanoes that show some of these characteristics, all with edifice heights in the range $1-2 \mathrm{~km}$. Nabro, Dubbi, and Oldoinyo Lengai show explosive eruptions with evolved magmas. Longonot, Oldoinyo Lengai, Nyamuragira, and Nyiragongo show evidence of radial dykes and a shallow central magma reservoir. Tibaldi et al. (2014) consider Nyiragongo to be an example of a volcano with a divergent rift system based on analysis of scoria cone distribution, but we argue that Nyiragongo does not have the highly elliptical footprint typical of such volcanoes and the splay of the rift fissures is better explained by transfer zone tectonics (Figure 7).

Overpressured magma reservoirs including major dykes (and sills) have yielded excellent InSAR signals in recent years that 
have been modeled in terms of the rise and partitioning of intrusive and extrusive volumes of magma. However, models have been unable to identify non-point source volumes for reservoirs and hence infer the $3 \mathrm{D}$ stress field. There is some evidence that the proportion of magma reaching the surface via rift-aligned dykes (e.g., DMH) is less than at more oblique dykes (e.g., Alayta).

However, Nyamuragira is the only EARS volcano with enough sufficiently well-documented eruptions to infer its longterm dynamic behavior. Stochastic modeling demonstrated a propensity for its shallow crustal reservoir to behave in a pressure-cooker/volume-limited manner (Burt et al., 1994) and exponential decay of extrusion rate decay during eruptions (Wadge and Burt, 2011). Eruptions within $7 \mathrm{~km}$ of the volcano are of relatively short duration ( $<100$ days), but eruptions with more distal fissures tend to have greater values of $\phi$ and longer durations. There were major changes in long-term magma extrusion rates in 1977 (and perhaps in 2002) due to major alongrift dyking events that effectively changed the Nyamuragira stress field and the intrusion/extrusion ratios of eruptions.

\section{REFERENCES}

Acocella, V. (2006). Regional and local tectonics at Erta Ale caldera, Afar (Ethiopia). J. Struct. Geol. 28, 1808-1820. doi: 10.1016/j.jsg.2006.06.014

Acocella, V., and Korme, T. (2002). Holocene extension direction along the Main Ethiopian Rift, East Africa. Terra Nova 14, 191-197. doi: 10.1046/j.13653121.2002.00403.x

Acocella, V., and Tibaldi, A. (2005). Dike propagation driven by volcano collapse: a general model tested at Stromboli, Italy. Geophys. Res. Lett. 32:L08308. doi: 10.1029/2004GL022248

Acocella, V., Korme, T., Salvini, F., and Funiciello, R. (2002). Elliptical calderas in the Ethiopian Rift: control of pre-existing structures. J. Volcanol. Geotherm. Res. 119, 189-203. doi: 10.1016/S0377-0273(02)00342-6

Acocella, V., and Neri, M. (2009). Dike propagation in volcanic edifices: overview and possible developments. Tectonophysics 471, 67-77. doi: 10.1016/j.tecto.2008.10.002

Acton, G. D., Stein, S., and Engeln, F. (1991). Block rotation and continental extension in Afar: a comparison to oceanic microplate systems. Tectonophysics 10, 501-526. doi: 10.1029/90tc01792

Albino, F., Smets, B., d'Oreye, N., and Kervyn, F. (2015). High resolution TanDEMX DEM: an accurate method to estimate lava flow volumes at Nyamuragira. J. Geophys. Res. Solid Earth 120, 4189-4207. doi: 10.1002/2015JB011988

Allard, P., Tazieff, H., and Dajlevic, D. (1979). Observations of seafloor spreading in Afar during the November 1978 fissure eruption. Nature 279, 30-33. doi: 10.1038/279030a0

Amadei, B., and Stephansson, O. (1997). Rock Stress and its Measurement. London: Chapman Hall.

Anderson, E. M. (1936). The dynamics of formation of cone sheets, ring dykes and cauldron subsidence. Proc. R. Soc. Edin. 56, 128-163. doi: 10.1017/S0370164600014954

Audin, J., Vellutini, P. J., Coulon, C., Piguet, P., and Vincent, J. (1990). The 19281929 eruption of Kammourta volcano - evidence of tectono-magmatic activity in the Manda-Inakir Rift and comparison with the Assal Rift, Afar Depression, Republic of Djibouti. Bull. Volcanol. 52, 551-561. doi: 10.1007/BF00301536

Ayalew, D., Dell'Erba, F., di Vito, M. A., Orsi, G., Yirgu, G., Dingwell, D., et al. (2006). The Da' Ure' eruption at the Boyna volcanic complex during the September 2005 Afar extension episode. Am. Geophys. Union, Fall Meeting Abstract T33E-02A.

Baer, G., Hamiel, Y., Shamir, G., and Nof, R. (2008). Evolution of a magma-driven earthquake swarm and triggering of the nearby Oldoinyo Lengai eruption, as resolved by InSAR, ground observations and elastic modelling, East African Rift, 2007. Earth Planet. Sci. Lett. 272, 339-352. doi: 10.1016/j.epsl.2008. 04.052

\section{AUTHOR CONTRIBUTIONS}

GW: Lead author. Instigator of idea. Chief editor of manuscript. Focus on historical volcanism. JB: Contribution mainly on InSAR and tectonics. RL: Responsible for work on calderas. JK: Responsible for material on seismic anisotropy.

\section{ACKNOWLEDGMENTS}

GW and JB are members of the NERC LICS (Looking Inside the Continents from Space) consortium (grant NE/K010956/1) and the Centre for the Observation and Modelling of Earthquakes, Volcanoes and Tectonics (COMET) network, JB and JK are supported by the NERC RiftVolc consortium (grant NE/L013932/1). RL is supported by a NERC studentship tied to LICS. All the research data are within the paper. We thank the editor and two anonymous referees for their reviews and Professor Agust Gudmundsson for his valuable advice on the relevance of the published results of numerical models of extensional stress fields.

Bagnardi, M., Amelung, F., and Poland, M. P. (2013). A new model for the growth of basaltic shields based on deformation. Earth Planet. Sci. Lett. 377, 358-366. doi: 10.1016/j.epsl.2013.07.016

Baker, B. H., Mohr, P. A., and Williams, L. A. J. (1972). Geology of the Eastern Rift System of Africa. Geol. Soc. Am. Spec. Pap. 136, 1-67. doi: 10.1130/SPE136-p1

Barberi, F., Borsi, S., Ferrara, G., Marinelli, G., and Varet, J. (1970). Relations between tectonics and magmatology in the northern Danakil Depression (Ethiopia). Phil. Trans. R. Soc. Lond. A 267, 293-311. doi: 10.1098/rsta.1970.0037

Barberi, F., and Varet, J. (1977). Volcanism of Afar: small scale plate tectonics implications. Bull. Geol. Soc. Am. 88, 1251-1266.

Barnie, T. D., Keir, D., Hamling, I., Hofmann, B., Belachew, M., Carn, S., et al. (2015). "A multidisciplinary study of the final episode of the Manda Hararo dyke sequence, Ethiopia and implications for trends in volcanism during rifting cycle," in Magmatic Rifting and Active Volcanism, eds T. J. Wright, A. Ayele, D. J. Ferguson, T. Kidane, and C. Vye-Brown (London: Geological Society), 420.

Batte, A. G., Rumpker, G., Lindenfeld, M., and Schuman, A. (2014). Structurally controlled seismic anisotropy above small earthquakes in crust rocks beneath the Ruwenzori region, Albertine Rift, Ugand. J. African Earth Sci. 100, 579-585. doi: 10.1016/j.jafrearsci.2014.08.001

Bialas, R. W., Buck, W. R., and Qin, R. (2010). How much magma is required to rift a continent? Earth Planet. Sci. 292, 68-78. doi: 10.1016/j.epsl.2010.01.021

Biggs, J., Anthony, E. Y., and Ebinger, C. J. (2009). Multiple inflation and deflation events at Kenyan volcanoes, East African Rift. Geology 37, 979-982. doi: 10.1130/G30133A.1

Biggs, J., Bastow, I. D., Keir, D., and Lewi, E. (2011). Pulses of deformation reveal frequently recurring shallow magmatic activity beneath the Main Ethiopian Rift. Geochem. Geophys. Geosystems. 12, Q0AB10. doi: 10.1029/2011gc003662

Biggs, J., Chivers, M., and Hutchinson, M. C. (2013a). Surface deformation and stress interactions during the 2007-2010 sequence of earthquakes, dyke intrusion and eruption in northern Tanzania. Geophys. J. Int. 195, 16-26. doi: $10.1093 /$ gji/ggt226

Biggs, J., Ebmeier, S. K., Aspinall, W. P., Lu, Z., Pritchard, M. E., Sparks, R. S. J., et al. (2014). Global link between deformation and volcanic eruption quantified by satellite imagery. Nat. Commun. 5:3471. doi: 10.1038/ncomms4471

Biggs, J., Nissen, E., Craig, T., Jackson, J., and Robinson, D. P. (2010). Breaking up the hanging wall of a rift-border fault: the 2009 Karonga earthquakes, Malawi. Geophys. Res. Lett. 37:L11305. doi: 10.1029/2010GL043179

Biggs, J., Robertson, E., and Cashman, K. (2016). The lateral extent of volcanic interactions during unrest and eruption. Nat. Geosci. 9, 308-311. doi: 10.1038/ ngeo2658

Biggs, J., Robertson, E., and Mace, M. (2013b). "ISMER - active magmatic processes in the East African Rift: a satellite radar perspective," in Remote 
Sensing Advances for Earth System Science, eds D. Fernandez-Prieto and R. Sabia (Berlin; Heidelberg: Springer), 81-91.

Bizouard, H., and Di Paula, G. M. (1979). "Mineralogy of the Tullu Moje active volcanic area (Arussi: Ethiopian Rift valley)," in Petrology and Geochemistry of Continental Rifts, eds E.-R. Neumann and I. B. Ramberg (Dordrecht: D. Reidel Co.), 87-100.

Bosworth, W., Burke, K., and Strecker, M. (2003). Effect of stress fields on magma chamber stability and the formation of collapse calderas. Tectonics 22, 1042. doi: 10.1029/2002TC001369

Brudy, M., Zoback, M. D., Fuchs, K., Rummel, F., and Baumgartner, J. (1997). Estimation of the complete stress tensor to $8 \mathrm{~km}$ depth in the KTB scientific drill holes: implications for crustal strength. J. Geophys. Res. 102, 18453-18475. doi: $10.1029 / 96 J B 02942$

Buck, W. R. (2004). "Consequences of asthenospheric variability on continental rifting," in Rheology and Deformation of the Lithosphere at Continental Margins, eds G. D. Karner, B. Taylor, N. W. Driscoll, and D. L. Kohlsted (New York, NY: Columbia University Press), 1-30.

Buck, W. R. (2006). "The role of magma in the development of the Afro-Arabian Rift System," in The Afar Volcanic Province within the East African Rift System, eds G. Yirgu, C. J. Ebinger, and P. K. H. Maguire (London: Geological Society), 259, 43-54.

Buck, W. R., Einarsson, P., and Bransdottir, B. (2006). Tectonic stress and magma chamber size as controls on dike propagation: constraints from the 1975-1984 Krafla rifting episode. J. Geophys. Res. 111, B12404. doi: 10.1029/2005jb003879

Burt, M. L., Wadge, G., and Scott, W. A. (1994). Simple stochastic modelling of the eruption history of a basaltic volcano: Nyamuragira, Zaire. Bull. Volcanol. 56, 87-97. doi: 10.1007/BF00304104

Calais, E., d'Oreye, N., Albaric, J., Deschamps, A., Delvaux, D., Déverchère, J., et al. (2008). Strain accommodation by slow slip and dyking in a youthful continental rift, East Africa. Nature 456, 783-787. doi: 10.1038/nature07478

Carboni, E., Grainger, R. G., Mather, T. A., Pyle, D. M., Thomas, G., Siddans, R., et al. (2015). The vertical distribution of volcanic $\mathrm{SO}_{2}$ plumes measured by IASI. Atmos. Chem. Phys. Discuss. 15, 24643-24693. doi: 10.5194/acpd-1524643-2015

Cattin, R., Doubre, C., de Chabalier, J.-B., King, G., Vigny, C., Avouac, J.-P., et al. (2005). Numerical modelling of Quaternary deformation and post-rifting displacement in the Asal-Ghoubbet rift (Djibouti, Africa). Earth Planet. Sci. Lett. 239, 352-367. doi: 10.1016/j.epsl.2005.07.028

Cavendish, H. S. H. (1897). Through Somaliland and around the south of Lake Rudolf. Geogr. J. 11, 372-393.

Champion, A. M. (1935). Teleki's Volcano and the lava fields at the southern end of Lake Rudolf. Geogr. J. 85, 323-336. doi: 10.2307/1785591

Chiodini, G., Caliro, S., De Martino, P., Avino, R., and Gherardai, F. (2012). Early signals of new volcanic unrest at Campi Flegrei caldera. Insights from geochemical data and physical simulations. Geology 40, 943-946. doi: $10.1130 / \mathrm{G} 33251.1$

CNR-CNRS Afar Team (1973). Geology of northern Afar (Ethiopia). Rev. Geog. Phys. Geol. Dynam. 15, 443-490.

Coblentz, D. D., and Sandiford, M. (1994). Tectonic stresses in the African plate: constraints of the ambient lithospheric stress state. Geology 22, 831-834.

Cole, J. W. (1969). The Gariboldi volcanic complex. Bull. Volcanol. 33, 566-578. doi: 10.1007/BF02596525

Condomines, M., Carpentier, M., and Ongendangenda, T. (2015). Extreme radium deficit in the 1957 AD Mugogo lava (Virunga volcanic field Africa): its bearing on olivine-melilitite genesis. Contrib. Mineral. Petrol. 169:29 doi: 10.1007/s00410-015-1124-9

Coppola, D., Campion, R., Laiolo, M., Cuoco, E., Balgizi, C., Ripepe, M., et al. (2016). Birth of a lava lake: Nyamuragira volcano 2011-2015. Bull. Volcanol. 78:20. doi: 10.1007/s00445-016-1014-7

Corbi, F., Rivalta, E., Pinel, V., Maccaferri, F., Bagnardi, M., and Acocella, V. (2015). How caldera collapse shapes the shallow emplacement and transfer of magma in active volcanoes. Earth Planet. Sci. Lett. 431, 287-293. doi: 10.1016/j.epsl.2015.09.028

Corti, G. (2009). Continental rift evolution from rift initiation to incipient breakup in the Main Ethiopian Rift, East Africa. Earth Sci. Rev. 96, 1-53. doi: 10.1016/j.earscirev.2009.06.005

Corti, G. (2012). Evolution and characteristics of continental rifting: analog modeling-inspired view and comparison with examples from the East African Rift System. Tectonophysics 522, 1-33. doi: 10.1016/j.tecto.2011.06.010
Craig, T. J., Jackson, J. A., Priestley, K., and McKenzie, D. (2011). Earthquake distribution patterns in Africa: their relationship to variations in lithospheric and geological structure, and their rheological implications. Geophys. J. Int. 185, 403-434. doi: 10.1111/j.1365-246X.2011.04950.x

Dahm, T. (2000). Numerical simulations of the propagation path and the arrest of fluid-filled fractures in the Earth. Geophys. J. Int. 141, 623-638. doi: 10.1046/j.1365-246x.2000.00102.x

De Chabalier, J.-B., and Avouac, J.-P. (1994). Kinematics of the Asal rift (Djibouti) determined from the deformation of Feale Volcano. Science 265, 1677-1681. doi: $10.1126 /$ science.265.5179.1677

Delvaux, D., and Barth, A. (2009). African stress pattern from formal inversion of focal mechanism data. Tectonophysics 482, 105-129. doi: 10.1016/j.tecto.2009.05.009

Dodson, R. G. (1963). The geology of the South Horr area. Rep. Geol. Surv. Kenya 60, 1-53.

Doubre, C., Manighetti, I., Dorbath, L., Dorbath, C., Bertil, D., and Delmond, J. C. (2007). Crustal structure and magmato-tectonic processes in an active rift (Asal-Ghoubbet, Afar, East Africa): 2. Insights from the 23-year recording of seismicity since the rifting event. J. Geophys. Res. 112:B05406. doi: 10.1029/2006 JB004333

Doubre, C., and Peltzer, G. (2007). Fluid-controlled faulting processes in the AsalRift, Djibouti, from 8-yr of radar interferometry observations. Geology 35, 69-72. doi: 10.1130/G23022A.1

Dunkley, P. N., Smith, M., Allen, D. J., and Darling, W. G. (1993). The geothermal activity and geology of the northern section of the Kenya Rift Valley. Br. Geol. Surv. Res. Rep. SC/93/1, 1-185.

Ebinger, C. J. (1989). Geometric and kinematic development of border faults and accommodation zones, Kivu-Rusizi Rift, Africa. Tectonics 8, 117-133. doi: 10.1029/TC008i001p00117

Ebinger, C. J. (2005). Continental break-up: the East African perspective. Astron. Geophys. 46, 2-16. doi: 10.1111/j.1468-4004.2005.46216.x

Ebinger, C. J. (2012). "Evolution of the Cenozoic East African Rift System: cratons, plumes and continental breakup," in Regional Geology and Tectonics. Phanerozoic Rift Systems and Sedimentary Basins, eds D. G. Robson and A. W. Bally (Amsterdam: Elsevier), 133-156.

Ebinger, C. J., Ayele, A., Keir, D., Rowland, J., Yirgu, G., Wright, T., et al. (2010). Length and timescales of rift faulting and magma intrusion: the Afar rifting cycle from 2005 to present. Annu. Rev. Earth Planet. Sci. 38, 439-466. doi: 10.1146/annurev-earth-040809-152333

Ferguson, D. J., Barnie, T. D., Pyle, D. M., Oppenheimer, C., Yirgu, G., Lewi, E., et al. (2010). Recent rift-related volcanism in Afar, Ethiopia. Earth Planet. Sci. Lett. 292, 409-418. doi: 10.1016/j.epsl.2010.02.010

Fernandez-Alonso, M., and Theunissen, K. (1998). Airborne geophysics and geochemistry provide new insights in the intracontinental evolution of the Mesoproterozoic Kibaran belt (Central Africa). Geol. Mag. 135, 203-216. doi: $10.1017 /$ S0016756898008310

Field, L., Barnie, T., Blundy, J., Brooker, R. A., Keir, D., Lewi, E., et al. (2012). Integrated field satellite and petrological observations of the November 2010 eruption of Erta Ale. Bull. Volcanol. 74, 2251-2271. doi: 10.1007/s00445-0120660-7

Fontijn, K., Delvaux, D., Ernst, G. G. J., Kervyn, M., Mbede, E., and Jacobs, P. (2010). Tectonic control over active volcanism at a range of scales: case of the Rungwe Volcanic Province, SW Tanzania; and hazard implications. J. Afr. Earth Sci. 5, 764-777. doi: 10.1016/j.jafrearsci.2009. 11.011

Fontijn, K., Williamson, D., Mbede, E., and Ernst, G. G. J. (2012). The Rungwe Volcanic Province, Tanzania - a volcanological review. J. Afr. Earth Sci. 63, 12-31. doi: 10.1016/j.jafrearsci.2011.11.005

Gibson, I. L. (1974). A review of the geology, petrology and geochemistry of the Volcano Fantale. Bull. Volcanol. 38, 791-802. doi: 10.1007/BF02596908

Goitom, B., Oppenheimer, C., Hammond, J. O., Grandin, R., Barnie, T., Donovan, A., et al. (2015). First recorded eruption of Nabro volcano, Eritrea, 2011. Bull. Volcanol. 77:85. doi: 10.1007/s00445-015-0966-3

Gouin, P. (1979). Earthquake History of Ethiopia and the Horn of Africa. Ottawa: International Development Research Centre.

Grandin, R., Socquet, A., Binet, R., Klinger, Y., Jacques, E., de Chabalier, J.-B., et al. (2009). September 2005 Manda Hararo-Dabbahu rifting event, Afar (Ethiopia): constraints provided by geodetic data. J. Geophys. Res. 114:B08404. doi: $10.1029 / 2008 J$ J005843 
Gudmundsson, A. (2000). Dynamics of volcanic systems in Iceland: example of tectonism and volcanism at juxtaposed hot spot and mid-ocean ridge systems. Annu. Rev. Earth Planet. Sci. 28, 107-140. doi: 10.1146/annurev.earth.28.1.107

Gudmundsson, A. (2003). Surface stresses associated with arrested dykes in rift zones. Bull. Volcanol. 65, 606-619. doi: 10.1007/s00445-003-0289-7

Gudmundsson, A. (2006). How local stresses control magma chamber ruptures, dyke injections, and eruptions in composite volcanoes. Earth Sci. Rev. 79, 1-31. doi: 10.1016/j.earscirev.2006.06.006

Gudmundsson, A. (2011a). Deflection of dykes into sills at discontinuities and magma chamber formation. Tectonophysics 500, 50-64. doi: 10.1016/j.tecto.2009.10.015

Gudmundsson, A. (2011b). Rock Fractures in Geological Processes. Cambridge: Cambridge University Press.

Gudmundsson, A. (2012). Magma chambers:formation,local stresses, excess pressures, and compartments. J. Volcanol. Geotherm. Res. 237-238, 19-41.

Gudmundsson, A., and Philipp, S. J. (2006). How local stress fields prevent volcanic eruptions. J. Volcanol. Geotherm. Res. 158, 257-268. doi: 10.1016/j.jvolgeores.2006.06.005

Gudmundsson, A., Simmenes, T. H., Larsen, B., and Philipp, S. L. (2010). Effects of internal structure and local stresses on fracture propagation, deflection and arrest in fault zones. J. Struct. Geol. 32, 1643-1655. doi: 10.1016/j.jsg.2009. 08.013

Hamling, I. J., Ayele, A., Bennati, L., Calais, E., Ebinger, C. J., Keir, D., et al. (2009). Geodetic observations of the ongoing Dabbahu rifting episode: new dyke intrusions in 2006 and 2007. Geophys. J. Int. 178, 989-1003. doi: 10.1111/j.1365246X.2009.04163.x

Hamlyn, J. E., Keir, D., Wright, T. J., Neuberg, J. W., Goitom, B., Hammond, J. O. S., et al. (2014). Seismicity and subsidence following the 2011 Nabro eruption, Eritrea: insights into the plumbing system of an off-rift volcano. J. Geophys. Res. Solid Earth 119, 8267-8282. doi: 10.1002/2014JB011395

Hammond, J. O. S. (2014). Constraining melt geometries beneath the Afar Depression, Ethiopia from teleseismic receiver functions: the anisotropic H-k stacking technique. Geochem. Geophys. Geosyst. 15, 1316-1332. doi: $10.1002 / 2013 \mathrm{gc} 005186$

Hammond, J. O. S., Kendall, J.-M., Wookey, J., Sturat, G. W., Keir, D., and Ayele, A. (2014). Differentiating flow, melt or fossil seismic anisotropy beneath Ethiopia. Geochem. Geophys. Geosyst. 15, 1878-1894. doi: 10.1002/2013gc005185

Harkin, D. A. (1960). The Rungwe volcanics at the northern end of Lake Nyasa. Geol. Survey Tanganyika Memoir II, 172.

Harris, A. J. L., Dehn, J., and Calvari, S. (2007). Lava effusion rate definition and measurement: a review. Bull. Volcanol. 70, 1-22. doi: 10.1007/s00445-0070120-y

Harris, W. C. (1844). The Highlands of Ethiopia, Vol. III. London: Longman, Brown, Green, Longmans.

Heidbach, O., Tingay, M., Barth, A., Reinecher, J., Kurfess, J., and Muller, B. (2010). Global crustal stress pattern based on the World Stress Map database release 2008. Tectonophysics 482, 3-15. doi: 10.1016/j.tecto.2009.07.023

Hutchison, W., Mather, T. A., Pyle, D. M., Biggs, J., and Yirgu, G. (2015). Structural controls on fluid pathways in an active rift system: a case study of the Aluto volcanic complex. Geosphere 11, 542-562. doi: 10.1130/GES01119.1

Isola, I., Mazzarini, F., Bonini, M., and Corti, G. (2014). Spatial variability of volcanic features in early-stage rift settings: the case of the Tanzanian Divergence, East African rift system. Terra Nova 26, 461-468. doi: $10.1111 /$ ter.12121

Karingithi, C. W., Arnorsson, S., and Gronvold, K. (2010). Processes controlling aquifer fluid compositions in the Olkaria geothermal system, Kenya. J. Volcanol. Geotherm. Res. 196, 57-56. doi: 10.1016/j.jvolgeores.2010.07.008

Keir, D., Bastow, I. D., Corti, G., Mazzarini, F., and Rooney, T. O. (2015). The origin of along-rift variations in faulting and magmatism in the Ethiopian Rift. Tectonics 34, 464-477. doi: 10.1002/2014TC003698

Keir, D., Belachew, M., Ebinger, C. J., Kendall, J.-M., Hammond, J. O. S., Stuart, G. W., et al. (2011a). Mapping the evolving strain field during continental breakup from crustal anisotropy in the Afar Depression. Nat. Commun. 2:285. doi : $10.1038 /$ ncomms 1287

Keir, D., Pagli, C., Bastow, I. D., and Ayele, A. (2011b). The magma assisted removal of Arabia in Afar: evidence from dike injection in the Ethiopian rift captured using InSAR and seismicity. Tectonics 30:TC2008. doi: 10.1029/2010TC002785

Kendall, J.-M., and Lithgow-Bertelloni, S. (2016). Why is Africa rifting? Geol. Soc. Lond. 420, 11-30. doi: 10.1144/SP420.17
Kendall, J.-M., Stuart, G. W., Ebinger, C. J., Bastow, I. D., and Keir, D. (2005). Magma-assisted rifting in Ethiopia. Nature 433, 146-148. doi: 10.1038 /nature 03161

Kervyn, M., Ernst, G. G. J., van Wyk de Vries, B., Mathieu, L., and Jacobs, P. (2009). Volcano load control on dyke propagation and vent distribution: insights from analogue modeling. J. Geophys. Res. 114:B03401. doi: 10.1029/2008jb005653

Kervyn, M., Ernst, G. J., Keller, J., Vaughan, R. G., Klaudius, J., Pradal, E., et al. (2010). Fundamental changes in the activity of the natrocarbonatite volcano Oldoinyo Lengai, Tanzania: eruptive behaviour during the 2007-2008 explosive eruptions. Bull. Volcanol. 72, 913-931. doi: 10.1007/s00445-010-0360-0

Komorowski, J.-C., Tedesco, D., Kasereka, M., Allard, P., Papale, P., Vaselli, O., et al. (2002). The January 2002 flank eruption of the Nyiragongo Volcano (Democratic Republic of Congo): chronology, evidence for a tectonic rift trigger and impact of lava flows on the city of Goma. Acta Vulcanol. 14, 27-62. doi: $10.1400 / 19077$

Koptev, A., Calais, E., Burov, E., Leroy, S., and Gerya, T. (2015). Dual continental rift systems generated by plume-lithosphere interaction. Nat. Geosci. 8, 388-392. doi: 10.1038/ngeo2401

Maccaferri, F., Acocella, V., and Rivalta, E. (2015). How the differential load induced by normal fault scarps controls the distribution of monogenetic volcanism. Geophys. Res. Lett. 42, 7507-7512. doi: 10.1002/2015GL065638

Maccaferri, F., Bonafede, M., and Rivalta, E. A. (2011). A quantitative study of the mechanisms governing dike propagation, dike arrest and sill formation. J. Volcanol. Geotherm. Res. 208, 39-50. doi: 10.1016/j.jvolgeores.2011.09.001

Maccaferri, F., Rivalta, E., Keir, D., and Accocella, V. (2014). Off-rift volcanism in rift zones determined by crustal unloading. Nat. Geosci. 7, 297-300. doi: $10.1038 /$ ngeo2 110

Marshall, A. S., Macdonald, R., Rogers, N. W., Fitton, J. G., Tindel, A. G., Nejbert, K., et al. (2009). Fractionation of peralkaline silicic magma: the Greater Olkaria Volcanic Complex, Kenya Rift Valley. J. Petrol. 50, 323-359. doi: 10.1093/petrology/egp001

Mazzarini, F., Keir, D., and Isola, I. (2013). Spatial relationship between earthquakes and volcanic vents in the central-northern Main Ethiopian Rift. J. Volcanol. Geotherm. Res. 262, 123-133. doi: 10.1016/j.jvolgeores.2013.05.007

McClusky, S., Reilinger, R., Ogubazhgi, G., Amelson, A., Healeb, B., Vernant, P., et al. (2010). Kinematics of the southern Red Sea-Afar triple junction and implications for plate dynamics. Geophys. Res. Lett. 37:L05301. doi: $10.1029 / 2009 \mathrm{gl} 1041127$

McGarr, A., and Gay, N. C. (1978). State of stress in the Earth's crust. Annu. Rev. Earth Planet. Sci. 6, 405-436. doi: 10.1146/annurev.ea.06.050178.002201

Mogi, K. (1958). Relations between eruptions of various volcanoes and the deformations of the ground surfaces around them. Bull. Earthq. Res. Inst. 36, 99-134.

Mohr, P. (1978). Afar. Annu. Rev. Earth Planet. Sci. 6, 145-172. doi: 10.1146/annurev.ea.06.050178.001045

Morley, C. K., Nelson, R. A., Patton, T. L., and Munn, S. G. (1990). Transfer zones in the East African Rift System and their relevance to hydrocarbon exploration in rifts. Bull. Am. Assoc. Petrol. Geologists 74, 1234-1253.

Muirhead, J. D., Kattenhorn, S. A., and Le Corvec, N. (2015). Varying styles of magmatic strain accommodation across the East African Rift. Geochem. Geophys. Geosystems 16, 2775-2795. doi: 10.1002/2015gc005918

Muller, O. H., and Pollard, D. D. (1977). The stress state near Spanish Peaks, Colorado, determined from a dike pattern. Pure Appl. Geophys. 115, 69-86. doi: 10.1007/BF01637098

Nakamura, K. (1977). Volcanoes as possible indicators of tectonic stress orientation - principle and proposal. J. Volcanol. Geotherm. Res. 2, 1-16. doi: 10.1016/0377-0273(77)90012-9

Nobile, A., Pagli, C., Keir, D., Wright, T. J., Ayele, A., Ruch, J., et al. (2012). Dikefault interaction during the 2004 Dallol intrusion at the northern edge of the Erta Ale Ridge (Afar, Ethiopia). Geophys. Res. Lett. 39:L19305. doi: 10.1029/ 2012gl053152

Nowacki, A., Wilks, M., Kendall, J.-M., Biggs, J., Ayele, A., Tulu, B., et al. (2016). Identifying Deformation Styles and Causes at Two Deforming Volcanoes of the Central Main Ethiopian Rift with Seismic Anisotropy (Vienna: EGU), EGU201611592.

Oppenheimer, C., and Francis, P. (1998). Implications of longeval lava lakes for geomorphological and plutonic processes at Erta Ale volcano, Afar. J. Volcanol. Geotherm. Res. 80, 101-111. doi: 10.1016/S0377-0273(97)00041-3

Pagli, C., Wang, H., Wright, T. J., Calais, E., and Lewi, E. (2014). Current plate boundary deformation of the Afar rift from a 3-D velocity field 
inversion of InSAR and GPS. J. Geophys. Res. Solid Earth 119, 8562-8575. doi: 10.1002/2014JB011391

Pagli, C., Wright, T. J., Ebinger, C., Yun, S.-H., Cann, J. R., Barnie, T., et al. (2012). Shallow axial magma chamber at the slow spreading Erta Ale Ridge. Nat. Geosci. 5, 284-288. doi: 10.1038/ngeo 1414

Pinel, V., and Jaupart, C. (2000). The effect of edifice load on magma ascent beneath a volcano. Phil. Trans. R. Soc. A 358, 1515-1532. doi: 10.1098/rsta.2000.0601

Rivalta, E., Taisne, B., Bunger, A. P., and Katz, R. F. (2015). A review of mechanical models of dyke propagation: schools of thought, results and future directions. Tectonophysics 638, 1-42. doi: 10.1016/j.tecto.2014.10.003

Robertson, E. A. M., Biggs, J., Cashman, K. V., and Floyd, M. A., Vye-Brown, C. (2015). "Influence of regional tectonics and pre-existing structures on the formation of elliptical calderas in the Kenyan Rift," in Magmatic Rifting and Active Volcanism, eds T. J. Wright, A. Ayele, D. J. Ferguson, T. Kidane, and C. Vye-Brown (London: Geological Society), 420.

Roman, A., and Jaupart, C. (2014). The impact of a volcanic edifice on intrusive and eruptive activity. Earth. Planet. Sci. Lett. 408, 1-8. doi: 10.1016/j.epsl.2014.09.016

Sachau, T., Koehn, D., Stamps, D. S., and Lindenfeld, M. (2015). Fault kinematics and stress fields in the Ruwenzori Mountains, Uganda. J. Int. Earth Sci. 105, 1729-1740. doi: 10.1007/s00531-015-1162-6

Saria, E., Calais, E., Stamps,. D. S., Delvaux, D., and Hartnady, C. J. H. (2014). Present-day kinematics of the East African Rift. J. Geophys. Res. 119, 3584-3600. doi: 10.1002/2013JB010901

Savage, M. K., Ohminato, T., Aoki, Y., Tsuji, H., and Greve, S. M. (2010). Stress magnitude and its temporal variation at Mt. Asama Volcano, Japan, from seismic anisotropy. Earth Planet. Sci. Lett. 290, 403-414. doi: 10.1016/j.epsl.2009.12.037

Savin, G. N. (1961). Stress Concentration around Holes. New York, NY: Pergamon.

Sawyer, G. M., Oppenheimer, C., Tsanev, V. I., and Yirgu, G. (2008). Magmatic degassing at Erta 'Ale volcano, Ethiopia. J. Volcanol. Geotherm. Res. 178, 837-846. doi: 10.1016/j.jvolgeores.2008.09.017

Scoon, R. (2015). Geotraveller 21: Tsavo, Chyulu Hills and Amboseli, Kenya: ancient landscapes and young volcanism. Geobulletin Geol. Soc. South Afr. 58, 45-51. doi: 10.13140/RG.2.1.3634.3206

Scott, S. (1980). The geology of Longonot volcano, central Kenya: a question of volumes. Phil. Trans. R. Soc. Lond. A 296, 437-465. doi: 10.1098/rsta.1980.0188

Sealing, C. R. (2013). Characterizing the First Historic Eruption of Nabro Eritrea: Insights from Thermal and UV Remote Sensing. Master's thesis, Michigan Technological University. Available online at: digitalcommons.mtu.edu/etds/ 646

Segall, P. (2010). Earthquake and Volcano Deformation. Princeton: Princeton University Press.

Skinner, N. J., Iles, W., and Brock, A. (1975). The secular variation of declination and inclination in Kenya. Earth Planet. Sci. Lett. 25, 338-346. doi: 10.1016/0012-821X(75)90251-4

Smets, B., Wauthier, C., and d'Oreye, N. (2010). A new map of the lava flow field of Nyamuragira (D.R.Congo) from satellite imagery. J. Afr. Earth Sci. 58, 778-786. doi: 10.1016/jafrearsci.2010.07.005

Spacapan, J. B., Galland, O., Leanza, H. A., and Planke, S. (2016). Control of strikeslip fault on dyke emplacement and morphology. J. Geol. Soc. 173, 573-576. doi: 10.1144/jgs2015-166

Spath, A., Le Roex, A. P., and Opiyo-Akech, N. (2000). The petrology of the Chyulu Hills Volcanic Province, southern Kenya. J. Afr. Earth Sci. 31, 337-358. doi: 10.1016/S0899-5362(00)00092-0

Stamps, D. S., Flesch, L. M., and Calais, E. (2010). Lithospheric buoyancy forces in Africa from a thin sheet approach. Int. J. Earth Sci. 99, 1525-1533. doi: 10.1007/s00531-010-0533-2

Stamps, D. S., Flesch, L. M., Calais, E., and Ghosh, A. (2014). Current kinematics and dynamics of Africa and the East African Rift System. J. Geophys. Res. Solid Earth 119, 5161-5186. doi: 10.1002/2013JB010717

Szpak, Z. L., Chojnacki, W., and van den Hengel, A. (2015). Guaranteed ellipse fitting with a confidence region and $n$ uncertainty measure for centre, axes and orientation. J. Math. Imaging Vis. 52, 173-199. doi: 10.1007/s10851-014-0536-x

Tarantola, A., Ruegg, J.-C., and Lepine, J. C. (1979). Geodetic evidence for rifting in Afar: a brittle-elastic model of the behaviour of the lithosphere. Earth Planet. Sci. Lett. 45, 435-444. doi: 10.1016/0012-821X(79)90142-0

Tazieff, H. (1977). An exceptional eruption: Mt. Nyiragongo, January $10^{\text {th }}, 1977$. Bull. Volcanol. 40, 1-12. doi: 10.1007/BF02596999
Tedesco, D., Vaselli, O., Papale, P., Carn, S. A., Voltaggio, M., Sawyer, G. M., et al. (2007). January 2002 volcano-tectonic eruption of Nyiragongo volcano, Democratic Republic of Congo. J. Geophys. Res. 112:B09202. doi: 10.1029/2006JB004762

Thompson, A. O. and Dodson, R. G. (1963). Geology of the Naivasha area. Rep. Geol. Surv. Kenya 55, 1-80.

Tibaldi, A. (2015). Structure of volcano plumbing systems: a review of multi-parametric effects. J. Volcanol. Geotherm. Res. 298, 85-135. doi: 10.1016/j.jvolgeores.2015.03.023

Tibaldi, A., Bonali, F. L., and Corazzato, C. (2014). The diverging volcanic rift system. Tectonophysics 611, 94-113. doi: 10.1016/j.tecto.2013.11.023

Toombs, A., and Wadge, G. (2012). Co-eruptive and inter-eruptive surface deformation measured by satellite radar interferometry at Nyamuragira volcano, D.R.Congo, 1996 to 2010. J. Volcanol. Geotherm. Res. 245-246, 98-122. doi: 10.1016/j.jvolgeores.2012.07.005

Tuckwell, G., Bull, J., and Sanderson, D. (1996). Models of fracture orientation at oblique spreading centres. J. Geol. Soc. Lond. 153, 185-189. doi: 10.1144/gsjgs.153.2.0185

Vellutini, P. (1990). The Manda-Inakir Rift, Republic of Djibouti: a comparison with the Asal Rift and its geodynamic interpretation. Tectonophysics 172, 141-153. doi: 10.1016/0040-1951(90)90065-G

Wadge, G., and Burt, L. (2011). Stress field control of eruption dynamics at a rift volcano: Nyamuragira, D.R.Congo. J. Volcanol. Geotherm. Res. 207, 1-15. doi: 10.1016/j.jvolgeores.2011.06.012

Walker, K. T., Nyblade, A. A., Klemperer, S. L., Bokelmann, G. H., and Owens, T. J. (2004). On the relationship between extension and anisotropy: constraints from shear wave splitting across the East African Plateau. J. Geophys. Res. Solid Earth 109:B08302. doi: 10.1029/2003jb002866

Wauthier, C., Cayol, V., Kervyn, F., and d'Oreye, N. (2012). Magma sources involved in the 2002 Nyiragongo eruption, as inferred from an InSAR analysis. J. Geophys. Res. 117:B05411. doi: 10.1029/2011JB008257

Wauthier, C., Cayol, V., Poland, M., Kervyn, F., d'Oreye, N., Hooper, A., et al. (2013). "Nyamulagira's magma plumbing system inferred from 15 years of InSAR," in Remote Sensing of Volcanoes and Volcanic Processes: Integrating Observations and Modelling, eds D. M. Pyle, T. A. Mather, and J. Biggs (London: Geological Society), 380.

Wiart, P. A. M., Oppenheimer, C., and Francis, P. (2000). Eruptive history of Dubbi volcano, northeast Afar (Eritrea), revealed by optical and SAR image interpretation. Int. J. Remote Sens. 21, 911-936. doi: 10.1080/014311600 210353

Wiart, P., and Oppenheimer, C. (2000a). Largest known historical eruption in Africa: Dubbi volcano, Eritrea, 1861. Geology 28, 291-294. doi: 10.1130/00917613(2000)28<291:LKHEIA > 2.0.CO;2

Wiart, P., and Oppenheimer, C. (2000b). Large magnitude silicic volcanism in north Afar: the Nabbro Volcanic Range and Ma'alatta volcano. Bull. Volcanol. 67, 99-115. doi: 10.1007/s00445-004-0362-x

Wood, D. A., Zal, H. J., Scholz, C. A., Ebinger, C. J., and Nizere, I. (2015). Evolution of the Kivu Rift, East Africa: interplay among tectonics, sedimentation and magmatism. Basin Res. doi: 10.1111/bre.12143. [Epub ahead of print].

Wright, T. J., Ebinger, C., Biggs, J., Ayele, A., Yirgu, G., Keir, D., et al. (2006). Magma-maintained rift segmentation at continental rupture in the 2005 Afar dyking episode. Nature 442, 291-294. doi: 10.1038/nature04978

$\mathrm{Xu}, \mathrm{W}$., and Jonsson, S. (2014). The 2007-8 volcanic eruption on Jebel at Tair island (Red Sea) observed by satellite radar and optical images. Bull. Volcanol. 76:795. doi: 10.1007/s00445-014-0795-9

Zal, H. J., Wood, D. A., Ebinger, C. J., Scholz, C. A., d'Oreye, N., Carn, S. A., et al. (2014). Kinematics and dynamics of the Kivu Rift System from seismic anisotropy, seismicity and structural analyses [Abstract]. AGU Fall Meeting 2014 abstract T53B-4676

Conflict of Interest Statement: The authors declare that the research was conducted in the absence of any commercial or financial relationships that could be construed as a potential conflict of interest.

Copyright (c) 2016 Wadge, Biggs, Lloyd and Kendall. This is an open-access article distributed under the terms of the Creative Commons Attribution License (CC BY). The use, distribution or reproduction in other forums is permitted, provided the original author(s) or licensor are credited and that the original publication in this journal is cited, in accordance with accepted academic practice. No use, distribution or reproduction is permitted which does not comply with these terms. 